\title{
Conceptual Modelling for Simulation: Progress and Grand Challenges
}

\author{
Stewart Robinson \\ School of Business and Economics \\ Loughborough University \\ Loughborough, LE11 $3 T U$ \\ UNITED KINGDOM \\ s.1.robinson@1boro.ac.uk
}

\begin{abstract}
In 2007 the Journal of Simulation ran what I believe was the first ever journal issue dedicated to the topic of conceptual modelling for discrete-event simulation. The editorial for that issue reported on a 2006 meeting of conceptual modelling researchers and highlighted a set of research themes in conceptual modelling. Just over ten years since that special issue this paper reviews the progress that has been made in conceptual modelling research through a timeline of key events and a review of the literature on the topic. It then sets out the grand challenges in conceptual modelling. Over the last ten years there has been significant activity on some research themes, especially conceptual modelling frameworks and conceptual model representation. There remain, however, many underexplored and unexplored themes. A number of themes, not anticipated in 2006, have also emerged. There is much more work to be done in conceptual modelling research. The grand challenges set out research areas that will be difficult to make progress in, but for which progress will have a significant impact.
\end{abstract}

\section{Key Words}

Discrete-Event Simulation, Conceptual Modelling, Literature Review, Grand Challenges 


\section{Conceptual Modelling for Simulation: Progress and Grand Challenges}

\section{Introduction}

In 2007 the Journal of Simulation ran a special issue on conceptual modelling for simulation. To the best of my knowledge this was the first special issue in any journal dedicated to this topic. The issue included six papers from authors who were leading research in the field. The editorial to the special issue argued that conceptual modelling is the most vital part of a simulation study, ensuring that a model is built at the right level of detail (Robinson, 2007). It also argued that conceptual modelling is the most difficult part of the process of developing and using a simulation model. Meanwhile, at the time there were only limited signs of research activity in conceptual modelling and with that, only a limited literature on the topic. The editorial did, however, suggest that this was starting to change and that greater signs of activity were starting to emerge.

The editorial describes a meeting of conceptual modelling researchers which took place in March 2006 ('2006 Conceptual Modelling Group'). The participants of this meeting, who all subsequently contributed to the Journal of Simulation special issue, were (affiliations are as at the time of the meeting): Roger Brooks (University of Lancaster), Kathy Kotiadis (University of Warwick), John Ryan (Dublin Institute of Technology), Sean Arthur (Virginia Tech), Durk-Jouke van der Zee (University of Groningen), Cathal Heavey (University of Limerick), Wang Wang (University of Lancaster), Richard Nance (ORCA Computer, Inc.) and Stewart Robinson (University of Warwick). The outcome of this one-day meeting was a set of research themes for conceptual modelling split between themes in the problem/modelling objectives domain and themes in the model domain. The list of research themes is reproduced in table 1. The topics identified were seen as a list of potential research areas required to move the field of conceptual modelling forward. The focus of those discussions was on conceptual modelling for discrete-event simulation. 
Table 1 Research Themes for Conceptual Modelling (Robinson, 2007)

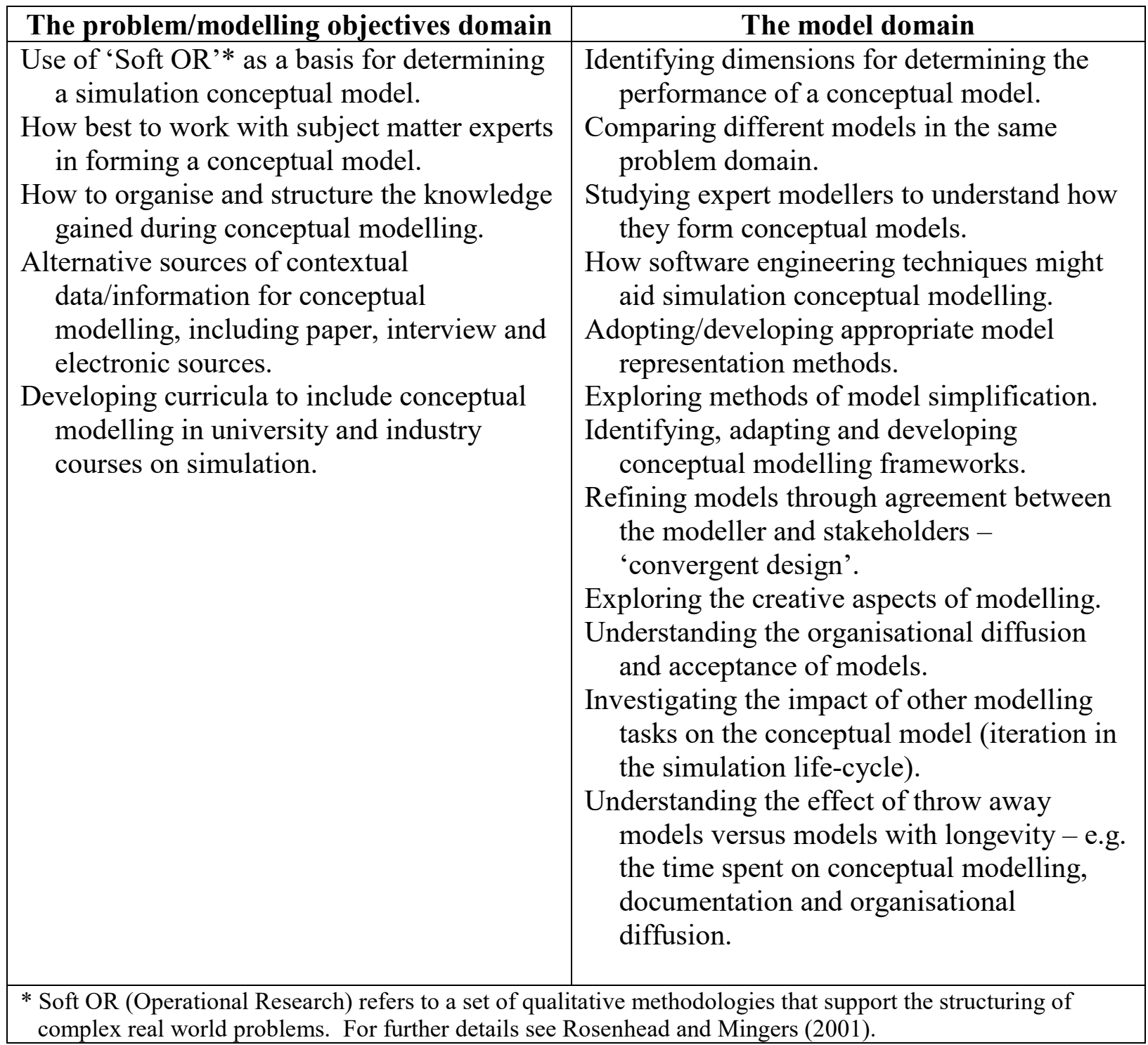

Now, just over ten years later, it would be useful to review what progress has been made in developing the field of conceptual modelling for simulation. That is the first purpose of this paper. Our aim is to understand whether the field has moved forward in the last ten years and the extent to which the research themes identified in 2007 have been addressed. To achieve this we perform a review of the literature from 2007 to early 2017. We also identify some key events which suggest that there has been progress in the conceptual modelling field. As with the 2006 meeting, our focus is on conceptual modelling for discrete-event simulation.

Our second purpose is to identify the 'grand challenges' in conceptual modelling research. That is, those challenges which are difficult, but not known to be insurmountable, and for which their solution will have a significant impact. The grand challenges are derived from 
the author's experience of more than 30 years working on conceptual modelling for simulation and by reflecting on the findings from the ten year retrospective.

I will not attempt to provide a detailed discussion on the nature and definition of conceptual modelling here, other than to say that it relates to the abstraction of a simulation model from the real world system that is being modelled. Because the simulation model is not a complete representation of the real world, conceptual modelling entails some element of simplification. More detailed discussions on the definition of conceptual modelling are provided in the literature referred to in this paper, but there is by no means full agreement. For a useful starting point, which identifies a range of opinions, I refer the reader to the panel discussion that took place at the 2015 Winter Simulation Conference (Robinson et al, 2015).

The paper is set out as follows. In the next section we discuss the key events in conceptual modelling over the last ten years, after which the approach to the literature search is described. The results from the literature review are then presented and discussed before setting out three grand challenges in conceptual modelling as well as a mini challenge. The paper finishes by summarising our main conclusions.

\section{Some Key Events in Conceptual Modelling}

Our history starts from 2007 following the Journal of Simulation special issue on conceptual modelling. This history is given as I have witnessed events unfold. I apologise for any inaccuracies or omissions, especially if there are other parallel activities of which I am not aware.

The Conceptual Modelling Group that met in 2006 continued to meet on a biennial basis following on from the UK Operational Research Society Simulation Workshop conferences in 2008, 2010 and 2012. The membership fluctuated, largely according to those who had attended the conference. These one-day meetings provided opportunities to discuss progress and identify actions for taking conceptual modelling forward. At the core of those actions were proposals for papers and sessions at the Winter Simulation Conference, continued sessions at the Simulation Workshop, and an edited book, subsequently published in 2011 (Robinson et al, 2011). Four core members led the group and held occasional teleconferences 
in between the meetings. In alphabetic order those members were: Roger Brooks, Cathal Heavey, Stewart Robinson and Durk-Jouke van der Zee.

In 2007, Kathy Kotiadis was awarded a £200k research grant from the UK Engineering and Physical Sciences Research Council (EPSRC) on the topic of conceptual modelling in the context of health services simulation. Antuela Tako (now at Loughborough University) worked on the project as a Research Associate. This work, which led to the PartiSim framework for participative simulation, contained a strong element of model conceptualisation based on a 'Soft OR' methodology (Tako and Kotiadis, 2015).

At the 2008 Winter Simulation Conference there were two sessions dedicated to conceptual modelling in the Modeling Methodology track. The first time there had been a full session on conceptual modelling at this conference was in 2006. The 2008 sessions covered the following topics: concepts of conceptual modelling, model reuse and composability, domain specific conceptual modelling and conceptual model representation. Since 2008 there have been many papers on conceptual modelling at the Winter Simulation Conference as evidenced by the references in this paper. There was also one session dedicated to the topic at the 2010 conference and then two sessions at the 2012 conference.

In 2011 there were two key events. Early in the year the edited book planned by the Conceptual Modelling Group was published (Robinson et al, 2011). The book includes 18 chapters that discuss the foundations of conceptual modelling, conceptual modelling frameworks, soft systems methodology for conceptual modelling, software engineering for conceptual modelling, and domain specific conceptual modelling. Authors came from across the globe and from a broad range of disciplines. Suffice to say, this was the first book dedicated to conceptual modelling for discrete-event simulation.

The other significant event in 2011 was the first Winter Simulation Conference tutorial on conceptual modelling (Robinson, 2011c). Since then, Introductory and Advanced Tutorials on conceptual modelling have featured every year at the conference (Robinson, 2012, 2013, 2015; Guizzardi and Wagner, 2012; Wagner, 2014; Arbez and Birta, 2016).

Two other significant events have been held at the Winter Simulation Conference. A panel discussion on conceptual modelling education led by Durk-Jouke van der Zee (van der Zee et 
al, 2010) and a panel discussion on the definition, purpose and benefits of conceptual modelling led by Stewart Robinson (Robinson et al, 2015). The latter brought together leading researchers with quite different perspectives on conceptual modelling and was a chance to review the current state of thinking about the topic. In the same year, Ric Roca led a similar panel discussion at the Spring Simulation Multi-Conference in Alexandria (USA) with input from Dale Pace, Stewart Robinson, Andreas Tolk and Levent Yilmaz (Roca et al, 2015). In 2015, Ric Roca also led the development of a US Department of Defense handbook on conceptual modelling with input from Stewart Robinson, Andreas Tolk and Levent Yilmaz.

The above points to a significant level of activity in the field of conceptual modelling over the last ten years. There is a sense of it becoming an established topic, especially at the Winter Simulation Conference. But to what extent has the field actually moved forward? Have the themes identified by the 2006 Conceptual Modelling Group (table 1) been addressed? We now turn our attention to answering these questions by reviewing the literature over the period 2007 to 2017.

\section{A Review of Literature on Conceptual Modelling (2007-2017)}

In order to identify literature published on conceptual modelling for discrete-event simulation in the last ten years and the themes that are addressed, an initial search was made for 'conceptual model simulation' in the Web of Science database. A broader search using terms such as 'software requirements' or 'elicitation' would have potentially identified some additional work on conceptual modelling for discrete-event simulation, but it would also have identified many papers with little relation to our field of interest. Besides, our interest is in those that identify their work as being in conceptual modelling for (discrete-event) simulation. If an author does not explicitly use those terms, then it is unlikely that the work is directly contributing to the field.

The Web of Science was chosen as it provides a wide ranging coverage of science and social science journals, as well as conference proceedings and scholarly books. It is expected that conceptual modelling work is primarily published in this range of outlets. Whilst search facilities such as Google Scholar would identify a much wider array of literature, the Web of 
Science has the benefit of offering a level of assurance of the quality of the outlet and so, by proxy, the published work.

For the years 2007 to 2017 the initial search identified 5,047 publications. The search was further refined by narrowing the topic categories to health care sciences services, computer science interdisciplinary applications, business or management, computer science theory methods, operations research management science, computer science information systems, engineering industrial, engineering manufacturing, and computer science software engineering. This reduced the publications to 1,116. The search was carried out in July 2017.

Following the automatic search, the publications were filtered manually, initially using the publication's title to determine if the work represented research or practice in simulation conceptual modelling. Of course, many publications had each of the three words 'conceptual', 'model' and 'simulation', but they did not necessarily involve a coherent discussion on conceptual modelling for simulation. Following this filtering process, the number of publications was reduced to 152 .

A final stage of manual filtering was carried out by reading the abstracts of the publications and where further information was required, by inspecting the full publication. Each publication was categorised according to the research theme in table 1 that it addresses. The aim was to identify the primary research theme that is addressed by each publication, but some works clearly addressed multiple themes at a significant level. Therefore, some articles were identified as addressing multiple themes. It was also clear that some of the publications addressed themes that were not identified by the 2006 Conceptual Modelling Group; these were categorised according to new themes that emerged during the categorisation (e.g. conceptual modelling case studies, automated code generation). During the filtering process, further publications were identified as not being relevant (e.g. they addressed conceptual modelling for system dynamics, agent based models or simulation games) and so they were removed. The final count of categorised publications found in the Web of Science was 108.

The Web of Science did not identify the six papers in the 2007 special issue of the Journal of Simulation (early volumes of the journal were not indexed), so these were added manually. Nor were the 18 chapters in the 2011 book on conceptual modelling found by the Web of 
Science. These were also added to the categorisation, giving a total of 132 publications on conceptual modelling for discrete-event simulation in the period 2007 to 2017.

The full categorisation of the identified publications is given in appendices A to C. Appendix A categorises publications that address themes in the problem/modelling objectives domain, appendix $\mathrm{B}$ categorises those that address themes in the model domain, and appendix $\mathrm{C}$ shows the new themes and the papers that address them.

Before discussing the results and findings from the review, it should be noted that no attempt has been made to filter out work that is essentially published more than once (e.g. as a conference paper, journal paper or book chapter), or that is only incremental and so secondary publications offer little in terms of new contributions to the field. Examples are Robinson's Winter Simulation Conference introductory tutorial which has been presented on four occasions and Onggo's work on model representation that appears in the Journal of Simulation in 2009 and then as a book chapter in 2011. As such, there is some bias in the analysis of publication counts by author, date and research theme if these were to be interpreted as unique contributions. As a measure of activity and interest by authors, on themes, over time, then inclusion of repeat and incremental contributions provides less of a concern with respect to bias.

\section{Results from the Literature Search}

In order to understand whether the conceptual modelling field has moved forward and the extent to which the research themes identified in table 1 have been addressed, the results from the literature search are presented in six ways. First we review a timeline showing the volume of publications by year and then we discuss the place of publication. Following this we identify the key authors in the field and the most highly cited publications. We then determine the volume of work carried out for each research theme, and finally we identify new research themes that were not identified by the 2006 Conceptual Modelling Group.

\subsection{Timeline of Conceptual Modelling Publications}

Figure 1 presents the number of publications on conceptual modelling identified in the literature search in each year from 2007 to 2017. Given the timing of the search, the 2017 
figure is for only part of the year. In the stacked bar chart the values are broken down into the number of journal papers, conference papers and book chapters. First we will focus on the total publications by year and then discuss the place of publication in the next sub-section.

Figure 1 Publications on Conceptual Modelling by Year

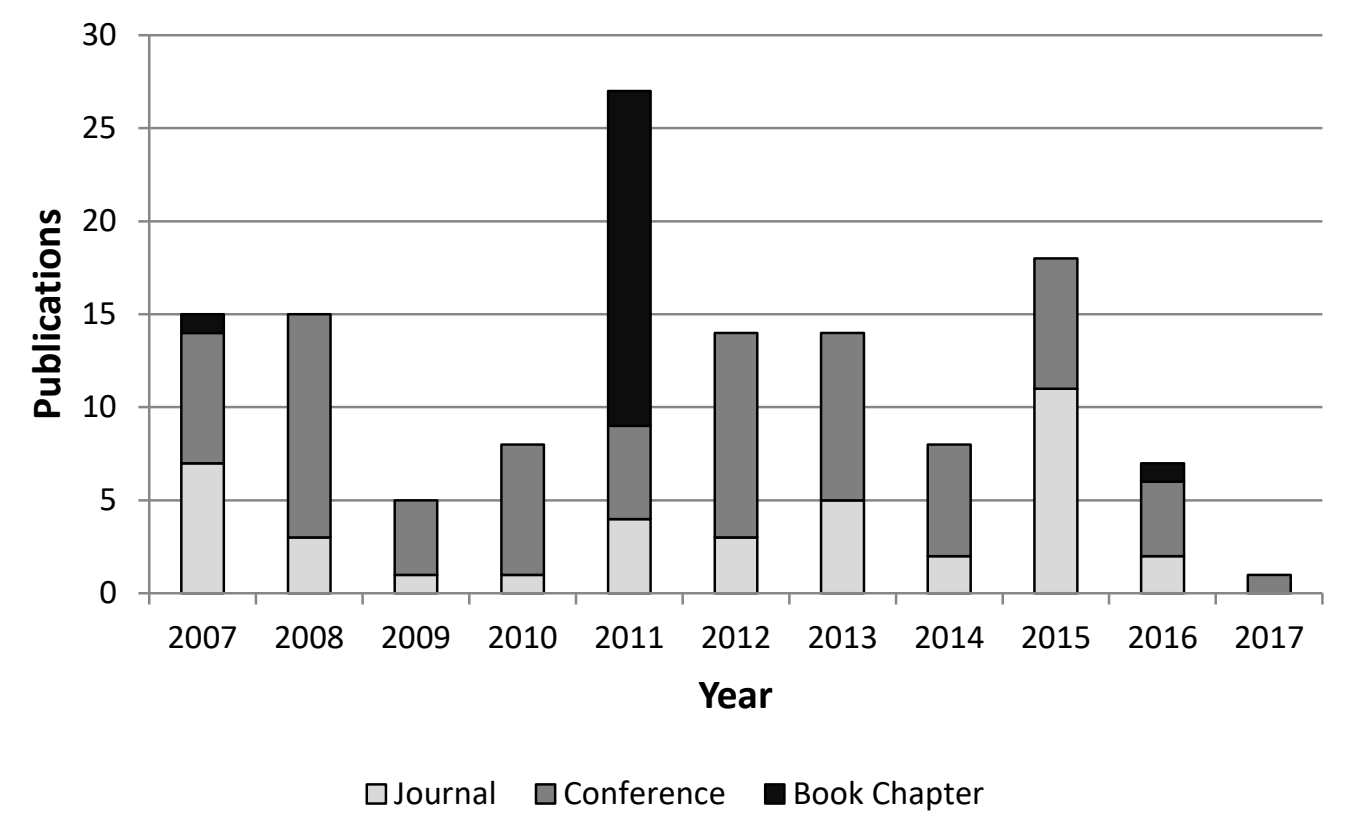

The peak of publications in 2011 is a result of the edited book on conceptual modelling, without which the number of conceptual modelling outputs would have been 18 fewer, that is, nine. Similarly, the 2007 figure includes the six papers from the Journal of Simulation special issue. Excluding the 2017 part year data, the mean number of articles per year has been 13.1. If the special issue and book chapters are excluded from the analysis, the mean reduces to 10.7 .

It is difficult to see any particular pattern in the timeline data. Certainly, there is no clear trend in the volume of publications. Had it not been for 2015, which has the highest number of independent publications (i.e. no special issues or books), there might be a concern that there is a downward trend. Indeed, ignoring the 2017 data, there is a small downward trend of 0.19 publications per annum from 2007 to 2016. However, if the publications from the special issue and conceptual modelling book are removed, this becomes a slight upward trend of 0.25 publications per annum. It seems sensible to conclude that there is effectively no 
trend in the data, but there has been a steady flow of papers between 5 and 15 per year over the period surveyed.

\subsection{Place of Publication}

In terms of the place of publication, figure 1 shows that there has been a steady flow of conference papers over the ten year period. As would be expected, the number has varied from year-to-year. The peak years of 2008 (12 conference papers) and 2012 (11 conference papers) coincide with the years when there were two sessions on conceptual modelling at the Winter Simulation Conference. According to figure 1, the peaks in journal papers occur in 2007 (7 papers) and 2015 (11 papers). The former figure is explained by the 2007 special issue of the Journal of Simulation. There is no apparent reason why such a high number of journal papers were published in 2015; the papers are scattered across a range of journals. There does appear to have been some increase in the volume of journal papers on conceptual modelling over the ten year period, but again, because the numbers vary so much year-onyear, it is difficult to detect a clear trend.

The outlets for the publications are dominated by the Winter Simulation Conference (45 papers) and the Journal of Simulation (16 papers). The Journal of the Operational Research Society published four papers on conceptual modelling between 2007 and 2017. Beyond that, the papers are scattered across a range of conferences and journals. For instance, there are two papers in both ACM Transactions on Modeling and Computer Simulation, and Simulation Modelling Practice and Theory.

\subsection{Key Authors on Conceptual Modelling}

Table 2 shows that there are nine authors who have published five or more articles during the ten year period under review. Four of these were members of the 2006 Conceptual Modelling Group: Robinson, van der Zee, Kotiadis and Brooks. Of the others, Tolk led a research group with an interest in conceptual modelling at Old Dominion University and now continues that interest while working for MITRE who provide modelling and simulation expertise for the US Government. Tako has worked with both Kotiadis and Robinson on conceptual modelling research. Four of Guizzardi's five publications are with Wagner. 
Meanwhile, Montevechi has generated an independent stream of work from his research group at the Federal University of Itajubá, Brasil.

Table 2 Leading Authors in Conceptual Modelling since 2007

\begin{tabular}{|l|c|}
\hline \multicolumn{1}{|c|}{ Author } & $\begin{array}{c}\text { Number of publications } \\
\text { since 2007 }\end{array}$ \\
\hline Robinson, S. & 15 \\
Tolk, A. & 12 \\
van der Zee, D-J. & 11 \\
Kotiadis, K. & 10 \\
Brooks, R.J. & 7 \\
Tako, A.A. & 6 \\
Wagner, G. & 6 \\
Guizzardi, G. & 5 \\
Montevechi, J.A.B. & 5 \\
\hline
\end{tabular}

These authors come from a range of disciplines. Robinson, Kotiadis, Tako and Brooks are all operational researchers and work in business/management schools. Similarly, van der Zee works in a faculty of economics and business and focuses on industrial engineering, operations research and operations management. Tolk's academic background is in engineering management and systems engineering, Wagner works in an Institute of Informatics and Guizzardi in a computer science department. Montevechi is an industrial engineer. These different disciplines are represented in the range of perspectives these authors bring to the topic of conceptual modelling.

\subsection{Most Cited Publications}

For the 132 shortlisted conceptual modelling publications, table 3 identifies those that have received 11 or more citations according to the Web of Science (search performed July 2017). This list contains many of the authors identified above as the most prolific writers on this theme, but it is notable that some different researchers appear: Cetinkaya et al, Onggo, Balci and McGinnis et al. Note that the paper by Turnitsa was published with Tolk. 
Table 3 Most Cited Publications (Citation Count from Web of Science, July 2017; Google Scholar, July 2018)

\begin{tabular}{|l|c|c|}
\hline \multicolumn{1}{|c|}{ Publication } & $\begin{array}{c}\text { Citations } \\
\text { WoS 2017 }\end{array}$ & $\begin{array}{c}\text { Citations } \\
\text { Google Scholar } \\
\mathbf{2 0 1 8}\end{array}$ \\
\hline Robinson (2008a) & 90 & 356 \\
\hline Robinson (2008b) & 39 & 136 \\
\hline Cetinkaya et al (2011) & 18 & 44 \\
\hline Montevechi et al (2010) & 18 & 79 \\
\hline Onggo (2009) & 16 & 33 \\
\hline Balci et al (2011) & 14 & 42 \\
\hline Tako et al (2010) & 12 & 32 \\
\hline Guizzardi and Wagner (2010) & 12 & 35 \\
\hline Balci et al (2008) & 12 & 29 \\
\hline Robinson (2013) & 11 & 42 \\
\hline McGinnis et al (2011) & 11 & 22 \\
\hline Turnitsa et al (2010) & 11 & 36 \\
\hline
\end{tabular}

For the purposes of comparison and to get a sense of their broader penetration, the total Google Scholar citations for the publications (as at July 2018) are listed in table 3. As would be expected, due to the broader scope of the literature included in Google Scholar, these are generally much higher than the Web of Science citation counts. The ordering of the publications would be changed slightly if the Google Scholar figures are used.

As the 2017 Web of Science search does not include the six papers in the 2007 special issue of the Journal of Simulation, nor the 18 chapters in the 2011 book on conceptual modelling, the Google Scholar citation counts for those publications were compared to the counts in table 3. Six of these additional publications have higher Google Scholar citation counts than McGinnis et al (2011) and so might have appeared in table 3 if they were indexed by the Web of Science. These publications are (Google Scholar citations given in brackets): Balci and Ormsby (2007) (61), Kotiadis (2007) (57), Wang and Brooks (2007a) (49), van der Zee (2007) (42), Tolk et al (2011) (27), and Karagöz and Demirörs (2011) (23). With the exception of Karagöz and Demirörs, all the key authors in this list appear at least once in table 2 or table 3.

Since the original Web of Science search in 2017, the Journal of Simulation has been fully indexed. As at 2019 the four Journal of Simulation papers listed above have the following citation counts in the Web of Science (citation count in brackets): Balci and Ormsby (2007) (25), Kotiadis (2007) (22), Wang and Brooks (2007a) (11), van der Zee (2007) (23). It is 
highly likely that three of these four papers would have appeared in table 3 based on 2017 data.

\subsection{Work Carried out on Each Research Theme}

Table 4 identifies all the research themes listed by the 2006 Conceptual Modelling Group for which subsequent publications have been identified, and the number of publications for each theme. The new themes identified during the categorisation also appear in this list. The full categorisation for each domain is given in appendices A, B and C.

Table 4 Frequency with which Themes have been Studied

\begin{tabular}{|c|c|c|}
\hline Category & $\begin{array}{c}\text { Theme } \\
\end{array}$ & Publications \\
\hline The model domain & $\begin{array}{l}\text { Identifying, adapting and developing } \\
\text { conceptual modelling frameworks }\end{array}$ & 32 \\
\hline The model domain & $\begin{array}{l}\text { Adopting/developing appropriate } \\
\text { model representation methods }\end{array}$ & 29 \\
\hline New theme & $\begin{array}{l}\text { Conceptual modelling and model } \\
\text { reuse, interoperability and } \\
\text { composability }\end{array}$ & 13 \\
\hline New theme & Concepts of conceptual modelling & 13 \\
\hline $\begin{array}{l}\text { The problem/ } \\
\text { objectives domain }\end{array}$ & $\begin{array}{l}\text { How to organise and structure the } \\
\text { knowledge gained during conceptual } \\
\text { modelling }\end{array}$ & 12 \\
\hline $\begin{array}{l}\text { The problem/ } \\
\text { objectives domain }\end{array}$ & $\begin{array}{l}\text { Use of 'Soft OR' as a basis for } \\
\text { determining a simulation conceptual } \\
\text { model }\end{array}$ & 11 \\
\hline The model domain & $\begin{array}{l}\text { How software engineering } \\
\text { techniques might aid simulation } \\
\text { conceptual modelling }\end{array}$ & 10 \\
\hline New theme & $\begin{array}{l}\text { Conceptual modelling and model } \\
\text { validation }\end{array}$ & 10 \\
\hline New theme & Automated code generation & 8 \\
\hline New theme & $\begin{array}{l}\text { Domain specific conceptual } \\
\text { modelling }\end{array}$ & 8 \\
\hline The model domain & $\begin{array}{l}\text { Identifying dimensions for } \\
\text { determining the performance of a } \\
\text { conceptual model }\end{array}$ & 7 \\
\hline The model domain & $\begin{array}{l}\text { Studying expert modellers to } \\
\text { understand how they form } \\
\text { conceptual models }\end{array}$ & 4 \\
\hline $\begin{array}{l}\text { The problem/ } \\
\text { objectives domain }\end{array}$ & $\begin{array}{l}\text { Developing curricula to include } \\
\text { conceptual modelling in university } \\
\text { and industry courses on simulation }\end{array}$ & 4 \\
\hline
\end{tabular}




\begin{tabular}{|l|l|c|}
\hline $\begin{array}{l}\text { The problem/ } \\
\text { objectives domain }\end{array}$ & $\begin{array}{l}\text { How best to work with subject } \\
\text { matter experts in forming a } \\
\text { conceptual model }\end{array}$ & 4 \\
\hline New theme & Conceptual modelling case studies & 3 \\
\hline The model domain & $\begin{array}{l}\text { Exploring methods of model } \\
\text { simplification }\end{array}$ & 2 \\
\hline
\end{tabular}

It is very clear that the primary focus of the research carried out in the last ten years has been on conceptual modelling frameworks and methods of representing conceptual models. Moderate attention has been given to model reuse, the conceptual foundations, organising knowledge, use of 'Soft OR' and software engineering, and model validation in relation to conceptual modelling. Other themes have received only limited attention, whilst the following themes have not been studied at all in the literature that has been identified:

- Alternative sources of contextual data/information for conceptual modelling, including paper, interview and electronic sources

- Comparing different models in the same problem domain

- Refining models through agreement between the modeller and stakeholders - 'convergent design'

- Exploring the creative aspects of modelling

- Understanding the organisational diffusion and acceptance of models

- Investigating the impact of other modelling tasks on the conceptual model (iteration in the simulation life-cycle)

- Understanding the effect of throw away models versus models with longevity - e.g. the time spent on conceptual modelling, documentation and organisational diffusion

These all belong in the model domain category with the exception of the first bullet that is in the problem/modelling objectives domain.

\subsection{New Research Themes}

As noted above, during the categorisation of the publications with respect to research themes, a number of new themes were identified. These are as follows:

- Conceptual modelling and model validation 
- Automated code generation

- Conceptual modelling case studies

- Domain specific conceptual modelling

- Concepts of conceptual modelling

- Conceptual modelling and model reuse, interoperability and composability

The number of publications for each of these themes is noted in table 4 .

\section{Discussion of Findings from the Literature Review}

With the more than ten years that has lapsed since the 2006 Conceptual Modelling Group identified a series of research themes and activities to develop the field of conceptual modelling, our first aim in this paper is to understand whether the field of conceptual modelling has moved forward and the extent to which the research themes identified in Robinson (2007) have been addressed. We have looked at this from the perspective of key events that have taken place in the last ten years and in terms of the literature that has been published on conceptual modelling for discrete-event simulation.

The key events clearly demonstrate a growing acceptance of conceptual modelling as an important and established topic in simulation research. Not least, regular tutorial sessions at the Winter Simulation Conference since 2011 suggest an acceptance that conceptual modelling is core to simulation and its practice. The emergence of tutorials, conference sessions, panel discussions, a book and a special issue have been substantially driven by a handful of researchers. Initially this was largely due to the members of the 2006 Conceptual Modelling Group, but since other key researchers such as Arbez, Birta, Tolk and Wagner have joined the advance.

Data on the volume of work being carried out, as determined by the number of publications per year, is a little disappointing. There has been no clear upward trend in publications, suggesting a field that could be described as 'not growing'. Of course, publication volume does not tell the whole story and what we have not attempted to measure is the quality of work over time or the extent to which research themes are actually being addressed. A steady rate of publication may signify steady progress that might itself be significant progress towards addressing the issues in the field. Alongside the volume of publications, the citation 
data points to a reasonable level of activity, including citations from a broader corpus of literature that is outside the immediate field of conceptual modelling for discrete-event simulation. The top 12 most cited publications average 22 citations, with the most cited having been referenced 90 times according to the Web of Science (as at July 2017). As expected, Google Scholar citation counts are much higher.

It is encouraging that authors are coming from a broad range of backgrounds, among them business, operational research, systems engineering, industrial engineering and computer science. The drawing together of different perspectives probably gives the greatest chance of addressing the complex technical, socio-technical and managerial issues involved in conceptual modelling.

The detailed review of which themes have been addressed by the literature in the last ten years highlights a strong focus on conceptual modelling frameworks and representing conceptual models. Much less attention has been given to other themes, with some that have not been investigated at all. The original discussions by the 2006 Conceptual Modelling Group made no attempt to prioritise the themes. The emergence of priority, or at least preferred, research themes is interesting, and it is encouraging to see the volume of work being carried out on frameworks and representation. The literature review also reveals six themes that were not anticipated by the 2006 Conceptual Modelling Group.

So, in answer to the questions posed at the end of section 2, we can say that the field of conceptual modelling has moved forward in the last ten years. We can also say that significant effort has gone into developing conceptual modelling frameworks and conceptual model representation methods. Alongside this, work has been carried out on many, but not all, of the themes identified by the 2006 Conceptual Modelling Group, and new themes have emerged over the last ten years. This surely represents progress, but the fact that today no agreed framework for conceptual modelling exists, and there is no standard way of representing conceptual models, suggests there is much room for further work on these, the most studied, themes. Not that a single standard is necessarily the ultimate or desirable aim. The more limited work on other themes also suggests more work is needed. Research on conceptual modelling is not done yet, indeed, it has probably only just started. 
In the next section we will turn our attention to the future and to the grand challenges in conceptual modelling for discrete-event simulation. But first we must acknowledge the limitations of the literature based work that has led to the results and findings above. The literature review was derived from the Web of Science, which is selective in the literature it reports. More conceptual modelling work no doubt exists in the wider academic literature and in practitioner based documents. In defence of the approach used in this paper, the Web of Science reports on 'quality' academic outlets and so assures some level of credibility of the work reported.

A further limitation is that the interpretation of the research theme addressed by a publication is subjective. There would almost certainly be some variance in the classification of publications if they were derived by a different researcher. However, potential misclassification is largely mitigated by the aggregation of publications by research theme; variance in the total publications classified by different researchers for each theme is unlikely to be large. Meanwhile, the lack of account for repeat publications is similarly likely to have a limited effect given the low volume of such publications, the aggregation by theme, and the focus on activity and interest in each theme rather than the uniqueness of the contribution.

Finally, volume of publications has been used as a proxy measure for progress. We have not attempted to measure the quality or contribution of a publication. In this respect, restricting the literature search to use of the Web of Science assures some level of quality. Assessing the progress made by each publication would be an altogether more complex and subjective task.

\section{Grand Challenges and Future Research in Conceptual Modelling}

So what of the future? What further research needs to be done? In particular, what are the grand challenges facing researchers in the field of conceptual modelling for discrete-event simulation? Our second aim is to identify those grand challenges.

Fowler and Rose (2004) describe a grand challenge as a problem with three facets:

- The solution may require multiple orders of magnitude improvement in capability across multiple dimensions 
- It is not provably insolvable

- The solution results in a significant economic and/or social impact

If we reflect on the research themes identified by the 2006 Conceptual Modelling Group, as well as the emerging themes from the literature review, we have a list of areas requiring further research. Although there has been progress on many of these themes, the need to continue research in these areas is as great today as it was in 2006. However, not many of these themes could be described as grand challenges according to the definition above. So what are the grand challenges in conceptual modelling for discrete-event simulation? Here I offer my views and identify three grand challenges and a mini challenge that we face. These views are based upon 30 years working on conceptual modelling for simulation and upon the findings from the ten year retrospective.

\subsection{Grand Challenge 1: Conceptual Modelling Itself}

In many respects the 2006 Conceptual Modelling Group were identifying conceptual modelling as a grand challenge in its own right. The list of research themes could be seen as the multiple dimensions across which there needs to be orders of magnitude of improvement in capability. Conceptual modelling is certainly difficult, but it is not provably insolvable. And if we could improve the efficiency and effectiveness of modelling through improved conceptualisation, then simulation could realise greater economic and societal benefits.

A key problem is a lack of agreement on the definition of a conceptual model. Robinson et al (2015) highlights quite significant differences in opinion. In the panel discussion Wagner states that a conceptual model describes the real world problem domain. Arbez and Birta take a similar view, defining a conceptual model as 'a concise and precise consolidation of all goal-relevant structural and behavioural features of the SUI [system under investigation].' Meanwhile, Robinson takes a very different view saying that the conceptual model describes the simulation model, that is, the abstraction from the real world. Tolk sees the conceptual model as embodying the 'abstract model' which is drawn from the 'target system' (real world). To make progress it would seem that a more unified definition and understanding of a conceptual model is needed, otherwise we are using the term to describe very different artefacts. 
At the core of the conceptual modelling grand challenge is the need to understand, research and practice the art of modelling. By nature, simulation is a technical field. Researchers and practitioners generally come from science, technology, engineering and mathematics backgrounds. This has surely focussed attention on the more 'scientific' elements of the simulation project life-cycle, that is, model development (led from computer science) and analysis (led from mathematics and statistics). This is reflected in the core tracks at the Winter Simulation Conference: modelling methodology and analysis methodology respectively. There is no track on the art of modelling.

Interestingly, the requirement for the art of modelling has been recognised from the very early days of simulation. The first book on simulation was titled 'The Art of Simulation' (Tocher, 1963). Shannon (1975) also recognised the need for art in simulation when titling his book 'Systems Simulation: the Art and Science'. Paul Fishwick, Distinguished University Chair of Arts, Technology, and Emerging Communication at UT Dallas, is one of the few contemporary simulation researchers that conjoins the world of arts and technology. Note that 'exploring the creative aspects of modelling' is one theme identified by the 2006 Conceptual Modelling Group that has not been studied at all according to the earlier literature review. If we are to make progress in conceptual modelling, we need to draw upon a broader set of research fields. In particular, we need to encompass and embrace research from the arts and even the humanities. Sessions and tracks on the art of modelling should be a regular feature at our conferences.

The two grand challenges that follow are both subsets of the overarching challenge of conceptual modelling. They also emerge from the earlier literature review as the themes to which most interest has already been paid.

\subsection{Grand Challenge 2: Developing Conceptual Modelling Frameworks}

Conceptual modelling frameworks is the most researched area in the last ten years, but we are still far from accepted ways of deriving the conceptual model. The lack of an agreed definition of the term 'conceptual model', as discussed above, does not help progress with this challenge. 
Many of the conceptual modelling research themes, both new and old, link to the development of conceptual modelling frameworks: how to organise and structure the knowledge gained during conceptual modelling, how software engineering techniques might aid simulation conceptual modelling, conceptual modelling and model validation, identifying dimensions for determining the performance of a conceptual model, studying expert modellers to understand how they form conceptual models, ... The development of frameworks is certainly a multidimensional problem requiring orders of magnitude improvement in capability.

It would seem unlikely that a single, accepted framework could emerge, and certainly there is merit in creating domain specific conceptual modelling frameworks. For instance, a framework for modelling health service problems could be very different to one that is aimed at logistics, manufacturing or transportation problems. By focussing on a specific domain it may be easier to create ways of aiding the conceptual modelling activity. As an example, Monks et al (2017) (this paper falls outside of the review period in sections 3 and 4) describe a domain specific conceptual modelling framework for hyperacute stroke systems. They discuss the benefits of increased efficiency against the wider applicability of a more general framework.

A potentially fruitful sub-theme to conceptual modelling frameworks is the study of model simplification methods. Providing modellers with standard ways of modelling problems more simply could provide significant benefits in speeding and simplifying model construction. Simpler models require less development time and less data. They also run faster and so improve the scope for experimentation. There have been some studies on model simplification, but very little recent work. Morris (1967) and Courtois (1985) both discuss methods that are applicable in the general context of modelling. Zeigler (1976), Innis and Rexstad (1983), Yin and Zhou (1989) and Robinson (1994) all discuss methods of model simplification specific to simulation modelling. Only two publications were identified in the literature review that covered the topic of model simplification: Moris et al (2008) and Koch and Tolujew (2013). A panel discussion at the 2018 Winter Simulation Conference, led by Durk-Jouke van der Zee, addresses model simplification from an educational perspective.

Another angle could be to look at conceptual modelling for other simulation approaches and for alternative uses of simulation. System dynamics modellers have a much more defined 
approach for conceptualising models, see, for instance, Wolstenholme (1990). Meanwhile, van der Zee et al (2012) discuss how conceptual models could be developed for 'serious games.' These might provide inspiration for improving conceptual modelling frameworks for discrete-event simulation.

Well defined and accepted conceptual modelling frameworks would also provide the foundation for improved education in conceptual modelling. Progress in educating students and modellers in conceptual modelling is also important if we are to see a step change in the quality of simulation models (van der Zee et al, 2010).

\subsection{Grand Challenge 3: Representation of Conceptual Models}

Being able to represent the conceptual model in a way that is meaningful, comprehensive and communicative remains a difficult, but surely not insurmountable, challenge. As the literature review shows, this is a popular research theme, but there is no agreed way of representing the model. This hampers progress.

If we look to a parallel simulation field, system dynamics, we see that there are very standard ways of representing models (Sterman, 2000). Causal loop diagrams are often used to describe the problem and these are converted into stock and flow diagrams which represent the model (Wolstenholme, 1990). These standard approaches provide a common language for understanding and agreeing the problem and the model.

To achieve such a standardised approach may not be possible for discrete-event simulation where the modelling frame is much more complex, but this does not mean that greater agreement and uniformity should not be sought. At the centre of this challenge is the lack of agreed definition of a conceptual model. Is it representing the problem domain or the model? More standardised representation methods also presupposes the purpose of a conceptual model is well understood. Is it a detailed description of the problem domain or is it a simplified representation of the model? Should the conceptual model representation support automated code generation or should it just be a means for agreeing on the broad concept of the model? This ties in to the level of elaboration required in the conceptual model representation. Again, a focus on domain specific approaches may be helpful for making progress in the representation of conceptual models. 


\subsection{A Mini Challenge: Linking Research and Practice}

Although I would not suggest that it is a grand challenge (because it cannot be that difficult to achieve), the need to link conceptual modelling research with conceptual modelling practice is nevertheless an important challenge. Those who regularly perform conceptual modelling in practice have much valuable information to impart to those who perform research. Meanwhile, conceptual modelling researchers need to test their ideas in the field of practice. It is imperative that researchers link with practice for their work to have economic and societal benefits.

The 2006 Conceptual Modelling Group was very keen that simulation practitioners are involved in research and development around conceptual modelling. However, in the literature review we found very little evidence of collaboration between academe and practice. Indeed, only three of the publications identified in the literature review were classified as case studies. The focus of work as identified in Table 4 suggests a bias towards method and tool development with little emphasis on conceptual modelling in practice. It appears that there remains a need for research in conceptual modelling to link with practice.

We need to create more opportunities for researchers and practitioners to collaborate. Conferences that draw workers from both domains are beneficial in this respect as are collaborative research projects. We should also seek more opportunities for researchers to work in practice through consulting and temporary assignments.

\section{Conclusion}

In this paper we have reviewed progress in the field of conceptual modelling for discreteevent simulation over the last ten years. Our aim has been to understand whether the field has moved forward and the extent to which the research themes identified in 2007 have been addressed. From our review of the literature from 2007 to 2017 we reach the following conclusions:

- There has been progress in conceptual modelling with 132 publications identified in the ten year period, but activity has been fairly constant with no obvious increase over time. 
- The Winter Simulation Conference and Journal of Simulation are the primary outlets for conceptual modelling research.

- Conceptual modelling researchers come from a range of core fields, among them: business, operational research, systems engineering, industrial engineering and computer science.

- The most active researchers in conceptual modelling come from four core groups: the 2006 Conceptual Modelling Group, and groups led by Tolk, Guizzardi and Wagner, and Montevechi.

- Research has primarily focused on conceptual modelling frameworks and conceptual model representation.

- A number of research themes identified by the 2006 Conceptual Modelling Group have not been addressed at all in the last ten years.

- New themes, not anticipated by the 2006 Conceptual Modelling Group, have emerged.

We then go on to identify three grand challenges in conceptual modelling research, namely: conceptual modelling itself, developing conceptual modelling frameworks, and representation of conceptual models. For each, suggestions on a way forward are given. A mini challenge is also identified, that is, to draw together more closely research and practice in conceptual modelling.

In summary, progress is being made, but there is still a lot to do. Conceptual modelling for discrete-event simulation remains a field ripe for on-going research.

\section{Acknowledgement}

This paper is extended from the conference paper: Robinson, S. (2018). Conceptual Modelling for Simulation: A Ten Year Review. Proceedings of the $9^{\text {th }}$ Simulation Workshop (SW18) (A. Anagnostou, R. Meskarian, D. Robertson, eds.), Operational Research Society, Birmingham. 


\section{References}

Adegoke, A., Togo, H., and Traore, M. K. (2013). A Unifying Framework for Specifying DEVS Parallel and Distributed Simulation Architectures. Simulation-Transactions of the Society for Modeling and Simulation International, 89(11), 1293-1309.

Ahmed, F., Robinson, S., and Tako, A. A. (2014). Using the Structured Analysis and Design Technique (SADT) in Simulation Conceptual Modeling. Proceedings of the 2014 Winter Simulation Conference (A. Tolk, S. D. Diallo, I. O. Ryzhov, L. Yilmaz, S. Buckley, and J. A. Miller, eds.), IEEE, Piscataway, NJ, pp. 1038-1049.

Al-Fedaghi, S. (2016). Conceptual Modeling in Simulation: A Representation that Assimilates Events. International Journal of Advanced Computer Science and Applications, 7(10), 281-289.

Arbez, G. and Birta, L.G. (2011). The ABCmod Conceptual Modeling Framework. Conceptual Modeling for Discrete-Event Simulation (Robinson, S., Brooks, R.J., Kotiadis, K. and van der Zee, D.-J., eds.). Chapman and Hall/CRC Boca Raton, FL, USA, pp. 133178.

Arbez, G. and Birta, L. G. (2016). A Tutorial on ABCmod: An Activity Based Discrete Event Conceptual Modelling Framework. Proceedings of the 2016 Winter Simulation Conference (T. M. K. Roeder, P. I. Frazier, R. Szechtman, E. Zhou, T. Huschka, and S. E. Chick, eds.), IEEE, Piscataway, NJ, pp. 88-102.

Arthur, J.D. and Nance, R.E. (2007). Investigating the Use of Software Requirements Engineering Techniques in Simulation Modelling. Journal of Simulation, 1 (3), pp. 159174.

Ayadi, M., Affonso, C. R., Cheutet, V., Masmoudi, F., Riviere, A., and Haddar, M. (2013). Conceptual Model for Management Of Digital Factory Simulation Information. International Journal of Simulation Modelling, 12(2), 107-119.

Bair, L. J. and Tolk, A. (2013). Towards a Unified Theory of Validation. Proceedings of the 2013 Winter Simulation Conference (R. Pasupathy, S.-H. Kim, A. Tolk, R. Hill, and M. E. Kuhl, eds). IEEE, Piscataway, NJ, pp. 1245-1256.

Balci, O. and Ormsby, W.F. (2007). Conceptual Modelling for Designing Large-Scale Simulation. Journal of Simulation, 1 (3), pp. 175-186.

Balci, O., Arthur, J. D. and Nance, R. E. (2008). Accomplishing Reuse with a Simulation Conceptual Model. Proceedings of the 2008 Winter Simulation Conference (S. J. Mason, R. R. Hill, L. Mönch, O. Rose, T. Jefferson, J. W. Fowler, eds.), IEEE, Piscataway, NJ, pp. 959-965. 
Balci, O., Arthur, J. D., and Ormsby, W. F. (2011). Achieving reusability and composability with a simulation conceptual model. Journal of Simulation, 5(3), 157-165.

Batarseh, O. G., Goldlust, E. J. and Day, T. E. (2013). SysML for Conceptual Modeling and Simulation for Analysis: A Case Example of a Highly Granular Model of an Emergency Department. Proceedings of the 2013 Winter Simulation Conference (R. Pasupathy, S.-H. Kim, A. Tolk, R. Hill, and M. E. Kuhl, eds). IEEE, Piscataway, NJ, pp. 2398-2409.

Brooks, R.J. (2011). Complexity, Level of Detail, and Model Performance. Conceptual Modeling for Discrete-Event Simulation (Robinson, S., Brooks, R.J., Kotiadis, K. and van der Zee, D.-J., eds.). Chapman and Hall/CRC Boca Raton, FL, USA, pp. 31-56.

Brooks, R. J., and Wang, W. (2015). Conceptual modelling and the project process in real simulation projects: a survey of simulation modellers. Journal of the Operational Research Society, 66(10), 1669-1685.

Cetinkaya, D., Verbraeck, A., and Seck, M. (2010). Towards a Component Based Conceptual Modeling Language for Discrete Event Simulation. (G. K. Janssens, K. Ramaekers, and A. Caris, Eds.), European Simulation and Modelling Conference 2010, pp. 67-74.

Cetinkaya, D., Verbraeck, A., and Seck, M. D. (2011). MDD4MS: A Model Driven Development Framework for Modeling and Simulation. In P. Kropf, A. Abhari, M. K. Traore, and H. Vakilzadian (Eds.), Proceedings of the 2011 Summer Computer Simulation Conference, pp. 113-121.

Cetinkaya, D., Verbraeck, A., and Seck, M. D. (2015). Model Continuity in Discrete Event Simulation: A Framework for Model-Driven Development of Simulation Models. $A C M$ Transactions on Modeling and Computer Simulation, 25(3).

Ceylan, A., and Gunal, M. M. (2011). A Methodology for Developing DES Models: Event Graphs and Sharpsim. (A. G. Bruzzone, M. A. Piera, F. Longo, P. Elfrey, M. Affenzeller, and O. Balci, Eds.), 23rd European Modeling \& Simulation Symposium, EMSS 2011, pp. 278-282.

Chwif, L., Banks, J., de Moura Filho, J. P., and Santini, B. (2013). A Framework for Specifying a Discrete-Event Simulation Conceptual Model. Journal of Simulation, 7(1), $50-60$.

Coatanea, E., Roca, R., Mokhtarian, H., Mokammel, F., and Ikkala, K. (2016). A Conceptual Modeling and Simulation Framework for System Design. Computing in Science \& Engineering, 18(4), 42-52.

Correia, G., and Viegas, J. M. (2009). A Conceptual Model for Carpooling Systems Simulation. Journal of Simulation, 3(1), 61-68. 
Courtois, P.J. (1985), On Time and Space Decomposition of Complex Structures. Communications of the ACM, 28 (6), 590-603.

de Assis Rangel, J. J., and Nunes, A. F. (2011). Use of IDEF-SIM to Document Simulation Models. Proceedings of the 2011 Winter Simulation Conference (S. Jain, R.R. Creasey, J. Himmelspach, K.P. White, and M. Fu, eds.), IEEE, Piscataway, NJ, pp. 1542-1553.

Dickmann, C., Klein, H., Birkhoelzer, T., Fietz, W., Vaupel, J., and Meyer, L. (2007).

Deriving a Valid Process Simulation from Real World Experiences. In Q. Wang and D. Pfanl (Eds.), Software Process Dynamics and Agility, Proceedings, pp. 272-282.

Durak, U., Oguztuzun, H., Algin, C. K., and Ozdikis, O. (2011). Towards Interoperable and Composable Trajectory Simulations: An Ontology-Based Approach. Journal of Simulation, 5(3), 217-229.

Ekelhart, A., Kiesling, E., Grill, B., Strauss, C., and Stummer, C. (2015). Integrating Attacker

Behavior in IT Security Analysis: A Discrete-Event Simulation Approach. Information Technology \& Management, 16(3), 221-233.

Figueras i Jove, J., Guasch i Petit, A., Fonseca i Casas, P., and Casanovas-Garcia, J. (2014).

Teaching System Modelling and Simulation Through Petri Nets and Arena. Proceedings of the 2014 Winter Simulation Conference (A. Tolk, S. D. Diallo, I. O. Ryzhov, L. Yilmaz, S. Buckley, and J. A. Miller, eds.), IEEE, Piscataway, NJ, pp. 3662-3673.

Fowler, J.W and Rose, O. (2004). Grand Challenges in Modeling and Simulation of Complex Manufacturing Systems. Simulation, 80 (9), 469-476.

Furian, N., O'Sullivan, M., Walker, C., Voessner, S., and Neubacher, D. (2015). A Conceptual Modeling Framework for Discrete Event Simulation using Hierarchical Control Structures. Simulation Modelling Practice and Theory, 56, pp. 82-96.

Gianni, D., D’Ambrogio, A., and Grasso, M. (2012). BOM2UML: Integrating BOM Specifications into UML-based Development Environments. In G. Wainer, P. Mosterman, A. Dambrogio, and G. Zacharewicz (Eds.), Theory of Modeling and Simulation: DEVS Integrative M\&S Symposium 2012, pp. 310-317.

Gore, R., Diallo, S., and Padilla, J. (2014). ConceVE: Conceptual Modeling and Formal Validation for Everyone. ACM Transactions on Modeling and Computer Simulation, 24(2). Grakova, E., Lenort, R., Wicher, P., and Tanger, L. (2014). Conceptual Framework for Computer Simulation of Supply Chain Resilience Building. CLC 2013: Carpathian Logistics Congress - Congress Proceedings, pp. 429-433.

Greenwood, A. G., Pawlewski, P. and Bocewicz, G., (2013). A Conceptual Design Tool to Facilitate Simulation Model Development: Object Flow Diagram. Proceedings of the 2013 
Winter Simulation Conference (R. Pasupathy, S.-H. Kim, A. Tolk, R. Hill, and M. E. Kuhl, eds). IEEE, Piscataway, NJ, pp. 1292-1303.

Gu, C., Jia, X., Liu, B., Wang, G., and Liu, H. (2013). Research on Validation Method of Dynamic Action of Equipment Maintenance Support Simulation Conceptual Model. In H. Z. Huang, Y. Liu, L. He, and M. J. Zuo (Eds.), Proceedings of 2013 International Conference on Quality, Reliability, Risk, Maintenance, and Safety Engineering (pp. 13791382).

Guizzardi, G., and Wagner, G. (2010). Towards an Ontological Foundation of Discrete Event Simulation. In B. Johansson, S. Jain, J. MontoyaTorres, J. Hugan, and E. Yucesan (Eds.), Proceedings of the 2010 Winter Simulation Conference (B. Johansson, S. Jain, J. Montoya-Torres, J. Hugan, and E. Yücesan, eds.), IEEE, Piscataway, NJ, pp. 652-664.

Guizzardi, G., and Wagner, G. (2012). Conceptual Simulation Modeling with ONTO-UML Advanced Tutorial. Proceedings of the 2012 Winter Simulation Conference (C. Laroque, J. Himmelspach, R. Pasupathy, O. Rose, and A.M. Uhrmacher, eds.), IEEE, Piscataway, NJ, pp. 52-66.

Guizzardi, G. and Wagner, G. (2013). Dispositions and Causal Laws as the Ontological Foundation of Transition Rules in Simulation Models. Proceedings of the 2013 Winter Simulation Conference (R. Pasupathy, S.-H. Kim, A. Tolk, R. Hill, and M. E. Kuhl, eds). IEEE, Piscataway, NJ, pp. 1335-1346.

Guizzardi, G., Wagner, G., Andrade Almeida, J. P., and Guizzardi, R. S. S. (2015). Towards Ontological Foundations for Conceptual Modeling: The Unified Foundational Ontology (UFO) Story. Applied Ontology, 10(3-4), 259-271.

Haveman, S. P., and Bonnema, G. M. (2015). Communication of Simulation and Modelling Activities in Early Systems Engineering. In J. Wade and R. Cloutier (Eds.), 2015 Conference on Systems Engineering Research, pp. 305-314.

Haydon, D. (2011). Conceptual Modeling in Practice: A Systematic Approach. Conceptual Modeling for Discrete-Event Simulation (Robinson, S., Brooks, R.J., Kotiadis, K. and van der Zee, D.-J., eds.). Chapman and Hall/CRC Boca Raton, FL, USA, pp. 211-227.

Hollmann, D. A., Cristia, M., and Frydman, C. (2015). CML-DEVS: A Specification Language for DEVS Conceptual Models. Simulation Modelling Practice and Theory, 57, 100-117.

Hou, B., Yao, Y. and Wang, B. (2008). Mapping from BOM Conceptual Model Definition to PDES Models for Enhancing Interoperability. 7th International Conference on System Simulation and Scientific Computing Asia Simulation Conference 2008, pp. 349-354. 
Innis, G. and Rexstad, E. (1983). Simulation Model Simplification Techniques. Simulation, $41(1), 7-15$.

James, K. C., and Bhasi, M. (2010). Development of Model Categories for Performance Improvement Studies Related to Airport Terminal Operations. Journal of Simulation, 4(2), 98-108.

James, K. C., and Bhasi, M. (2012). Some Aspects of Domain Specific Conceptual Modeling for Simulation of Logistic Terminal Operations. In World Congress on Engineering and Computer Science, WCECS 2012, Vol II, pp. 1372-1376.

Johansson, M., Johansson, B., Skoogh, A., Leong, S., Riddick, F., Lee, Y. T., Shao, G. and Klingstam, P. (2007). A Test Implementation of the Core Manufacturing Simulation Data Specification. Proceedings of the 2007 Winter Simulation Conference (Henderson, S.G., Biller, G., Hsieh, M.-H., Shortle, J., Tew, J.D., Barton, R.R., eds.), IEEE, Piscataway, NJ, pp. 1673-1681.

Karagöz, N.A. and Demirörs, O. (2011). Conceptual Modeling Notations and Techniques. Conceptual Modeling for Discrete-Event Simulation (Robinson, S., Brooks, R.J., Kotiadis, K. and van der Zee, D.-J., eds.). Chapman and Hall/CRC Boca Raton, FL, USA, pp. 179209.

Kilic, O., Say, B. and Demirors, O. (2008). Cognitive Aspects of Error Finding on a Simulation Conceptual Modeling Notation. 23rd International Symposium on Computer and Information Sciences, pp. 1-6.

Koch, M., Tolujew, J., and Schenk, M. (2012). Approaching Complexity in Modeling and Simulation of Logistics Systems (WIP). In G. Wainer, P. Mosterman, A. Dambrogio, and G. Zacharewicz (Eds.), Theory of Modeling and Simulation: DEVS Integrative M\&S Symposium 2012, pp. 25-30.

Koch, M., and Tolujew, J. (2013). Grouping Logistics Objects for Mesoscopic Modeling and Simulation of Logistics Systems. (W. Rekdalsbakken, R. T. Bye, and H. Zhang, Eds.), Proceedings 27th European Conference on Modelling and Simulation ECMS 2013, pp. 636-643.

Kotiadis, K. (2007). Using Soft Systems Methodology to Determine the Simulation Study Objectives. Journal of Simulation, 1 (3), pp. 215-222.

Kotiadis, K. (2011). Using Soft Systems Methodology in Conceptual Modeling: A Case Study in Intermediate Health Care. Conceptual Modeling for Discrete-Event Simulation (Robinson, S., Brooks, R.J., Kotiadis, K. and van der Zee, D.-J., eds.). Chapman and Hall/CRC Boca Raton, FL, USA, pp. 255-276. 
Kotiadis, K., Tako, A. A., and Vasilakis, C. (2014). A Participative and Facilitative Conceptual Modelling Framework for Discrete Event Simulation Studies in Healthcare. Journal of the Operational Research Society, 65(2), 197-213.

Kotiadis, K. and Robinson, S. (2008). Conceptual Modelling: Knowledge Acquisition and Model Abstraction. Proceedings of the 2008 Winter Simulation Conference (S. J. Mason, R. R. Hill, L. Mönch, O. Rose, T. Jefferson, J. W. Fowler, eds.), IEEE, Piscataway, NJ, pp. 951-958.

Liston, P. Kabak, K.E., Dungan, P., Byrne, J., Young, P. and Heavey, C. (2011). An Evaluation of SysML to Support Simulation Modeling. Conceptual Modeling for DiscreteEvent Simulation (Robinson, S., Brooks, R.J., Kotiadis, K. and van der Zee, D.-J., eds.). Chapman and Hall/CRC Boca Raton, FL, USA, pp. 279-307.

Liu, B., Gu, H., and Wang, H. (2016). A Conceptual Modeling Method of Simulation System Based on MCM. In P. Jiang and X. Liang (Eds.), Proceedings of the 2016 5th International Conference on Advanced Materials and Computer Science, pp. 400-405.

Liu, Y., and Iijima, J. (2015). Business Process Simulation in the Context of Enterprise Engineering. Journal of Simulation, 9(3), pp. 206-222.

Loper, M. L., Birta, L. G., and Arbez, G. (2012). Lessons from a Conceptual Modeling Exercise. Proceedings of the 2012 Winter Simulation Conference (C. Laroque, J. Himmelspach, R. Pasupathy, O. Rose, and A.M. Uhrmacher, eds.), IEEE, Piscataway, NJ, pp. 3735-3746.

Luetjen, M., and Rippel, D. (2015). GRAMOSA Framework for Graphical Modelling and Simulation-Based Analysis of Complex Production Processes. International Journal of Advanced Manufacturing Technology, 81(1-4), pp. 171-181.

McGinnis, L., Huang, E., Kwon, K. S., and Ustun, V. (2011). Ontologies and Simulation: A Practical Approach. Journal of Simulation, 5(3), pp. 190-201.

Mensah, P., Merkuryev, Y., Klavins, E., and Manak, S. (2017). Supply Chain Risks Analysis of a Logging Company: Conceptual Model. In E. Ginters and J. Kohlhammer (Eds.), ICTE 2016, pp. 313-320.

Monks, T., van der Zee, D. J., Lahr, M., Allen, M., Pearn, K., James, M. A., Buskens, E., and Luijckx, G. J. (2017). A Framework to Accelerate Simulation Studies of Hyperacute Stroke Systems. Operations Research for Health Care, 15, pp. 57-67.

Montevechi, J. A., da Silva Costa, R. F., Leal, F., de Pinho, A. F., Silva Marins, F. A. and Marins, F. F. (2008). Combined use of Modeling Techniques for the Development of the Conceptual Model in Simulation Projects. Proceedings of the 2008 Winter Simulation 
Conference (S. J. Mason, R. R. Hill, L. Mönch, O. Rose, T. Jefferson, J. W. Fowler, eds.), IEEE, Piscataway, NJ, pp. 987-995.

Montevechi, J. A., Leal, F., de Pinho, A. F., da Silva Costa, R. F., Moura de Oliveira, M. L., and Faustino da Silva, A. L. (2010). Conceptual Modeling in Simulation Projects by Mean Adapted IDEF: An Application in a Brazilian Tech Company. Proceedings of the 2010 Winter Simulation Conference (B. Johansson, S. Jain, J. Montoya-Torres, J. Hugan, and E. Yücesan, eds.), IEEE, Piscataway, NJ, pp. 1624-1635.

Montevechi, J. A., and Friend, J. D. (2012). Using a Soft Systems Methodology Framework to Guide the Conceptual Modeling Process in Discrete Event Simulation. Proceedings of the 2012 Winter Simulation Conference (C. Laroque, J. Himmelspach, R. Pasupathy, O. Rose, and A.M. Uhrmacher, eds.), IEEE, Piscataway, NJ, pp. 3699-3710.

Montevechi, J. A., Moura de Oliveira, M. L., Leal, F., and de Pinho, A. F. (2014). Analysis of the Applicability of the IDEF-SIM Modeling Technique to the Stages of a Discrete Event Simulation Project. Proceedings of the 2014 Winter Simulation Conference (A. Tolk, S. D. Diallo, I. O. Ryzhov, L. Yilmaz, S. Buckley, and J. A. Miller, eds.), IEEE, Piscataway, NJ, pp. 950-961.

Moris, M. U., Ng, A. H. C. and Svensson, J. (2008). Simplification and Aggregation Strategies Applied for Factory Analysis in Conceptual Phase using Simulation. Proceedings of the 2008 Winter Simulation Conference (S. J. Mason, R. R. Hill, L. Mönch, O. Rose, T. Jefferson, J. W. Fowler, eds.), IEEE, Piscataway, NJ, pp. 1913-1921.

Morris, W.T. (1967). On the Art of Modeling. Management Science, 13 (12), B707-717.

Neumann, G. (2007). Conceptual Framework for Knowledge Management Support in Logistics and Supply Chain Simulation. (D. Aldabass, R. Zobel, A. Abraham, and S. Turner, Eds.), AMS 2007: First Asia International Conference on Modelling \& Simulation Asia Modelling Symposium, Proceedings, pp. 507-514.

Onggo, B. S. S. (2009). Towards a unified conceptual model representation: a case study in healthcare. Journal of Simulation, 3(1), 40-49.

Onggo, S. (2011). Methods for Conceptual Model Representation. Conceptual Modeling for Discrete-Event Simulation (Robinson, S., Brooks, R.J., Kotiadis, K. and van der Zee, D.-J., eds.). Chapman and Hall/CRC Boca Raton, FL, USA, pp. 337-354.

Onggo, B. S. S., and Hoare, S. (2011). Online Collaborative Simulation Conceptual Model Development. (A. G. Bruzzone, M. A. Piera, F. Longo, P. Elfrey, M. Affenzeller, and O. Balci, Eds.), 23rd European Modeling \& Simulation Symposium, EMSS 2011, pp. 333-339. 
Ozhan, G., and Oguztuzun, H. (2013). Data and Behavior Decomposition for the ModelDriven Development of an Executable Simulation Model. In G. A. Wainer, P. Mosterman, G. Zacharewicz, and F. Barros (Eds.), Symposium on Theory of Modeling \& Simulation DEVS Integrative M\&S Symposium, pp. 153-161.

Pace, D.K. (2011). Conceptual Modeling Evolution within US Defense Communities: The View from the Simulation Interoperability Workshop. Conceptual Modeling for DiscreteEvent Simulation (Robinson, S., Brooks, R.J., Kotiadis, K. and van der Zee, D.-J., eds.). Chapman and Hall/CRC Boca Raton, FL, USA, pp. 423-449.

Pels, H. J., and Goossenaerts, J. (2007). A Conceptual Modeling Technique for Discrete Event Simulation of Operational Processes. In J. Olhager and F. Persson (Eds.), Advances in Production Management Systems, pp. 305-312.

Pereira, T. F., Montevechi, J. A., Miranda, R. de C., and Friend, J. D. (2015). Integrating Soft Systems Methodology to Aid Simulation Conceptual Modeling. International Transactions in Operational Research, 22(2), 265-285.

Pidd, M. (2011). Making Sure you Tackle the Right Problem: Linking Hard and Soft methods in Simulation Practice. Conceptual Modeling for Discrete-Event Simulation (Robinson, S., Brooks, R.J., Kotiadis, K. and van der Zee, D.-J., eds.). Chapman and Hall/CRC Boca Raton, FL, USA, pp. 231-253.

Powell, J., and Mustafee, N. (2014). Soft OR Approaches in Problem Formulation Stage of a Hybrid M\&S Study. Proceedings of the 2014 Winter Simulation Conference (A. Tolk, S. D. Diallo, I. O. Ryzhov, L. Yilmaz, S. Buckley, and J. A. Miller, eds.), IEEE, Piscataway, NJ, pp. $1664-1675$.

Robinson, S. (1994). Simulation Projects: Building the Right Conceptual Model. Industrial Engineering, 26 (9), 34-36.

Robinson, S. (2007). The Future's Bright the Future's...Conceptual Modelling for Simulation! Journal of Simulation, 1 (3), pp. 149-152.

Robinson, S. (2008a). Conceptual Modelling for Simulation Part I: Definition and Requirements. Journal of the Operational Research Society, 59(3), 278-290.

Robinson, S. (2008b). Conceptual Modelling for Simulation Part II: A Framework for Conceptual Modelling. Journal of the Operational Research Society, 59(3), 291-304. 
Robinson, S. (2011a). Conceptual Modelling for Simulation: Definition and Requirements. Conceptual Modeling for Discrete-Event Simulation (Robinson, S., Brooks, R.J., Kotiadis, K. and van der Zee, D.-J., eds.). Chapman and Hall/CRC Boca Raton, FL, USA, pp. 3-30. Robinson, S. (2011b). A Framework for Simulation Conceptual Modeling. Conceptual Modeling for Discrete-Event Simulation (Robinson, S., Brooks, R.J., Kotiadis, K. and van der Zee, D.-J., eds.). Chapman and Hall/CRC Boca Raton, FL, USA, pp. 73-101.

Robinson, S. (2011c). Choosing the Right Model: Conceptual Modeling for Simulation. Proceedings of the 2011 Winter Simulation Conference (S. Jain, R.R. Creasey, J. Himmelspach, K.P. White, and M. Fu, eds.), IEEE, Piscataway, NJ, pp. 1428-1440.

Robinson, S., Brooks, R.J., Kotiadis, K. and van der Zee, D.-J. (2011). Conceptual Modelling for Discrete-Event Simulation. Chapman and Hall/CRC Boca Raton, FL, USA.

Robinson, S. (2012). Tutorial: Choosing what to Model - Conceptual Modeling for Simulation. Proceedings of the 2012 Winter Simulation Conference (C. Laroque, J. Himmelspach, R. Pasupathy, O. Rose, and A.M. Uhrmacher, eds.), IEEE, Piscataway, NJ, pp. 1909-1920.

Robinson, S. (2013). Conceptual Modeling for Simulation. Proceedings of the 2013 Winter Simulation Conference (R. Pasupathy, S.-H. Kim, A. Tolk, R. Hill, and M. E. Kuhl, eds). IEEE, Piscataway, NJ, pp. 377-388.

Robinson, S. (2015). A Tutorial on Conceptual Modeling for Simulation. Proceedings of the 2015 Winter Simulation Conference (L. Yilmaz, W. K. V. Chan, I. Moon, T. M. K. Roeder, C. Macal, and M. D. Rossetti, eds.), IEEE, Piscataway, NJ, pp. 1820-1834.

Robinson, S., Arbez, G., Birta, L. Tolk, A. and Wagner, G. (2015). Conceptual Modeling: Definition, Purpose and Benefits. Proceedings of the 2015 Winter Simulation Conference (L. Yilmaz, W. K. V. Chan, I. Moon, T. M. K. Roeder, C. Macal, and M. D. Rossetti, eds.), IEEE, Piscataway, NJ, pp. 2812-2826.

Roca, R., Pace, D., Robinson, S., Tolk, A. and Yilmaz, L. (2015). Paradigms for Conceptual Modeling. 2015 Spring Simulation Multi-Conference, The Society for Modeling \& Simulation International , pp. 202-209.

Rosenhead, J. and Mingers J. (2001). Rational Analysis for a Problematic World Revisited. Wiley, Chichester, UK.

Ryan, J. and Heavey, C. (2007). Development of a Process Modelling Tool for Simulation. Journal of Simulation, 1 (3), pp. 203-214.

Ryan, J. and Heavey, C. (2011). Development of a Process Modeling Tool for Simulation. Conceptual Modeling for Discrete-Event Simulation (Robinson, S., Brooks, R.J., Kotiadis, 
K. and van der Zee, D.-J., eds.). Chapman and Hall/CRC Boca Raton, FL, USA, pp. 309336.

Sales, T. P., and Guizzardi, G. (2015). Ontological Anti-Patterns: Empirically Uncovered Error-Prone Structures in Ontology-Driven Conceptual Models. Data \& Knowledge Engineering, 99, pp. 72-104.

Sarli, J. L., Leone, H. P., and De los Milagros Gutierrez, M.(2016). Ontology-Based Semantic Model of Supply Chains for Modeling and Simulation in Distributed Environment. Proceedings of the 2016 Winter Simulation Conference (T. M. K. Roeder, P. I. Frazier, R. Szechtman, E. Zhou, T. Huschka, and S. E. Chick, eds.), IEEE, Piscataway, NJ, pp. 1182-1193.

Setavoraphan, K., and Grant, F. H., (2008). Conceptual Simulation Modeling: The Structure of Domain Specific Simulation Environment. Proceedings of the 2008 Winter Simulation Conference (S. J. Mason, R. R. Hill, L. Mönch, O. Rose, T. Jefferson, J. W. Fowler, eds.), IEEE, Piscataway, NJ, pp. 975-986.

Shannon, R.E. (1975). Systems Simulation: the Art and Science. Prentice-Hall, Englewood Cliffs, NJ.

Silver, G. A., Bellipady, K. R., Miller, J. A., Kochut, K. J. and York, W. (2009). Supporting Interoperability using the Discrete-Event Modeling Ontology (DeMO). Proceedings of the 2009 Winter Simulation Conference (M. D. Rossetti, R. R. Hill, B. Johansson, A. Dunkin, and R. G. Ingalls, eds.), IEEE, Piscataway, NJ, pp. 1399-1410.

Sprenger, R. and Rose, O. (2011). On the Simplification of Semiconductor Wafer Factory Simulation Models. Conceptual Modeling for Discrete-Event Simulation (Robinson, S., Brooks, R.J., Kotiadis, K. and van der Zee, D.-J., eds.). Chapman and Hall/CRC Boca Raton, FL, USA, pp. 451-470.

Sterman, J.D. (2000). Business Dynamics: Systems Thinking and Modeling for a Complex World. McGraw-Hill, New York.

Sun, W., Bai, Y., Zhang, X., and Gu, C. (2013). Research on the Conceptual Modeling Method Base on System Six-view and Ontology. In T. Hu (Ed.), Proceedings of the 2013 the International Conference on Artificial Intelligence and Software Engineering, pp. 231-234.

Sung, C., and Kim, T. G. (2012). Collaborative Modeling Process for Development of Domain-Specific Discrete Event Simulation Systems. IEEE Transactions on Systems Man and Cybernetics Part C-Applications and Reviews, 42(4), pp. 532-546. 
Tako, A. A., Kotiadis, K., and Vasilakis, C. (2010). A Participative Modelling Framework for Developing Conceptual Models in Healthcare Simulation Studies. Proceedings of the 2010 Winter Simulation Conference (B. Johansson, S. Jain, J. Montoya-Torres, J. Hugan, and E. Yücesan, eds.), IEEE, Piscataway, NJ, pp. 500-512.

Tako, A. A., and Kotiadis, K. (2012). Facilitated Conceptual Modelling: Practical Issues and Reflections. Proceedings of the 2012 Winter Simulation Conference (C. Laroque, J. Himmelspach, R. Pasupathy, O. Rose, and A.M. Uhrmacher, eds.), IEEE, Piscataway, NJ, pp. 3711-3722.

Tako, A. A., and Kotiadis, K. (2015). PartiSim: A Multi-Methodology Framework to Support Facilitated Simulation Modelling in Healthcare. European Journal of Operational Research, 244(2), pp. 555-564.

Tanriöver, Ö.Ö., Bilgen, S. (2011). UML-Based Conceptual Models and V\&V. Conceptual Modeling for Discrete-Event Simulation (Robinson, S., Brooks, R.J., Kotiadis, K. and van der Zee, D.-J., eds.). Chapman and Hall/CRC Boca Raton, FL, USA, pp. 383-419.

Tocher, K.D. (1963). The Art of Simulation. The English Universities Press, London.

Tolk, A., and Turnitsa, C. D. (2007). Conceptual Modeling of Information Exchange Requirements Based on Ontological Means. Proceedings of the 2007 Winter Simulation Conference (Henderson, S.G., Biller, G., Hsieh, M.-H., Shortle, J., Tew, J.D., Barton, R.R., eds.), IEEE, Piscataway, NJ, pp. 1100-1107.

Tolk, A., Diallo, S. Y. and Turnitsa, C. D. (2008a). Mathematical Models Towards SelfOrganizing Formal Federation Languages Based on Conceptual Models of Information Exchange Capabilities. Proceedings of the 2008 Winter Simulation Conference (S. J. Mason, R. R. Hill, L. Mönch, O. Rose, T. Jefferson, J. W. Fowler, eds.), IEEE, Piscataway, NJ, pp. 966-974.

Tolk, A., Litwin, T. G. and Kewley, R. H. (2008b). A Systems Engineering Process Supporting the Development of Operational Requirements Driven Federations. Proceedings of the 2008 Winter Simulation Conference (S. J. Mason, R. R. Hill, L. Mönch, O. Rose, T. Jefferson, J. W. Fowler, eds.), IEEE, Piscataway, NJ, pp. 1296-1304.

Tolk, A., Diallo, S.Y., King, R.D., Turnitsa, C.D. and Padilla, J.J. (2011). Conceptual Modeling for Composition of Model-Based Complex Systems. Conceptual Modeling for Discrete-Event Simulation (Robinson, S., Brooks, R.J., Kotiadis, K. and van der Zee, D.-J., eds.). Chapman and Hall/CRC Boca Raton, FL, USA, pp. 355-381. 
Tolk, A., and Turnitsa, C. (2012). Conceptual Modeling with Processes. Proceedings of the 2012 Winter Simulation Conference (C. Laroque, J. Himmelspach, R. Pasupathy, O. Rose, and A.M. Uhrmacher, eds.), IEEE, Piscataway, NJ, pp. 2641-2653.

Tolk, A. (2015). Modeling and Simulation Interoperability Concepts for Multidisciplinarity, Interdisciplinarity, and Transdisciplinarity - Implications for Computational Intelligence Enabling Autonomous Systems. In J. Hodicky (Ed.), Modelling and Simulation for Autonomous Systems, Mesas 2015, pp. 60-74.

Turner, A. J. and Mavris, D. N. (2015). Conceptual Modeling and Validation of a HA/DR Scenario Using a Weighted System Decomposition Model. Proceedings of the 2015 Winter Simulation Conference (L. Yilmaz, W. K. V. Chan, I. Moon, T. M. K. Roeder, C. Macal, and M. D. Rossetti, eds.), IEEE, Piscataway, NJ, pp. 2487-2498.

Turnitsa, C. and Tolk, A. (2008). Knowledge Representation and the Dimensions of a MultiModel Relationship. Proceedings of the 2008 Winter Simulation Conference (S. J. Mason, R. R. Hill, L. Mönch, O. Rose, T. Jefferson, J. W. Fowler, eds.), IEEE, Piscataway, NJ, pp. 1148-1156.

Turnitsa, C., Padilla, J. J., and Tolk, A. (2010). Ontology for Modeling and Simulation. Proceedings of the 2010 Winter Simulation Conference (B. Johansson, S. Jain, J. Montoya-Torres, J. Hugan, and E. Yücesan, eds.), IEEE, Piscataway, NJ, pp. 643-651.

van der Zee, D.J. (2007). Developing Participative Simulation Models - Framing Decomposition Principles for Joint Understanding. Journal of Simulation, 1 (3), pp. 187202.

van der Zee, D.J. and van der Vorst, J. G. A. J. (2007). Guiding Principles for Conceptual Model Creation in Manufacturing Simulation. Proceedings of the 2007 Winter Simulation Conference (Henderson, S.G., Biller, G., Hsieh, M.-H., Shortle, J., Tew, J.D., Barton, R.R., eds.), IEEE, Piscataway, NJ, pp. 776-784.

van der Zee, D.J., and Holkenborg, B. (2010). Conceptual Modelling for Simulation-Based Serious Gaming. Proceedings of the 2010 Winter Simulation Conference (B. Johansson, S. Jain, J. Montoya-Torres, J. Hugan, and E. Yücesan, eds.), IEEE, Piscataway, NJ, pp. 522534.

van der Zee, D.J., Kotiadis, K., Tako, A. A., Pidd, M., Balci, O., Tolk, A., and Elder, M. (2010). Panel Discussion: Education on Conceptual Modeling for Simulation Challenging the Art. Proceedings of the 2010 Winter Simulation Conference (B. Johansson, S. Jain, J. Montoya-Torres, J. Hugan, and E. Yücesan, eds.), IEEE, Piscataway, NJ, pp. 290-304. 
van der Zee, D.J. (2011). Building Insightful Simulation Models using Petri Nets - A

Structured Approach. Decision Support Systems, 51(1), pp. 53-64.

van der Zee, D.J. (2011). Developing Participative Simulation Models: Framing

Decomposition Principles for Joint Understanding. Conceptual Modeling for Discrete-

Event Simulation (Robinson, S., Brooks, R.J., Kotiadis, K. and van der Zee, D.-J., eds.).

Chapman and Hall/CRC Boca Raton, FL, USA, pp. 103-132.

van der Zee, D.J., Brooks, R.J., Robinson, S. and Kotiadis, K. (2011). Conceptual Modelling:

Past, Present and Future. Conceptual Modeling for Discrete-Event Simulation (Robinson,

S., Brooks, R.J., Kotiadis, K. and van der Zee, D.-J., eds.). Chapman and Hall/CRC Boca

Raton, FL, USA, pp. 473-490.

van der Zee, D.J. (2012). An Integrated Conceptual Modeling Framework for Simulation -

Linking Simulation Modeling to the Systems Engineering Process. Proceedings of the

2012 Winter Simulation Conference (C. Laroque, J. Himmelspach, R. Pasupathy, O. Rose, and A.M. Uhrmacher, eds.), IEEE, Piscataway, NJ, pp. 3723-3734.

van der Zee, D.J., Holkenborg, B., and Robinson, S. (2012). Conceptual Modeling for

Simulation-Based Serious Gaming. Decision Support Systems, 54(1), pp. 33-45.

van der Zee, D.J., Lahr, M. M. H., Luijckx, G.-J. and Buskens, E. (2015). Simulation

Conceptual Modeling for Optimizing Acute Stroke Care Organization. Proceedings of the

2015 Winter Simulation Conference (L. Yilmaz, W. K. V. Chan, I. Moon, T. M. K. Roeder,

C. Macal, and M. D. Rossetti, eds.), IEEE, Piscataway, NJ, pp. 1403-1414.

Wagner, G. (2014). Tutorial: Information and Process Modeling for Simulation. Proceedings of the 2014 Winter Simulation Conference (A. Tolk, S. D. Diallo, I. O. Ryzhov, L. Yilmaz, S. Buckley, and J. A. Miller, eds.), IEEE, Piscataway, NJ, pp. 103-117.

Wang, J., Yang, H., Zhao, Y. and Zhang, C. (2009). Mapping from BOM Conceptual Model

Definition to Ontology for Verifying Semantic Matching Simulation Components. Fifth International Conference on Semantics, Knowledge and Grid, pp. 402-403.

Wang, W. and Brooks, R.J. (2007a). Improving the Understanding of Conceptual Modelling. Journal of Simulation, 1 (3), pp. 153-158.

Wang, W. and Brooks, R. J. (2007b). Empirical Investigations of Conceptual Modeling and the Modeling Process. Proceedings of the 2007 Winter Simulation Conference (Henderson, S.G., Biller, G., Hsieh, M.-H., Shortle, J., Tew, J.D., Barton, R.R., eds.), IEEE, Piscataway, NJ, pp. 762-770.

Wang, W. and Brooks, R.J. (2011). Improving the Understanding of Conceptual Modeling. Conceptual Modeling for Discrete-Event Simulation (Robinson, S., Brooks, R.J., Kotiadis, 
K. and van der Zee, D.-J., eds.). Chapman and Hall/CRC Boca Raton, FL, USA, pp. 5770 .

Wolstenholme, E. F. (1990). System Enquiry: A System Dynamics Approach. Wiley, Chichester, UK.

Yaroker, Y., Perelman, V., and Dori, D. (2013). An OPM Conceptual Model-Based Executable Simulation Environment: Implementation and Evaluation. Systems Engineering, 16(4), 381-390.

Yavari, E., and Roeder, T. (2012). Model Enrichment: Concept, Measurement, and Application. Journal of Simulation, 6(2), 125-140.

Yilmaz, L. (2007). Using Meta-Level Ontology Relations to Measure Conceptual Alignment and Interoperability of Simulation Models. Proceedings of the 2007 Winter Simulation Conference (Henderson, S.G., Biller, G., Hsieh, M.-H., Shortle, J., Tew, J.D., Barton, R.R., eds.), IEEE, Piscataway, NJ, pp. 1090-1099.

Yin, H.Y. and Zhou , Z.N. (1989). Simplification Techniques of Simulation Models. Proceedings of Beijing International Conference on System Simulation and Scientific Computing, pp. 782-786.

Zainuddin, F., Ali, N. M., Sidek, R. M., Romli, A., Talib, N. and Ibrahim, M. I. (2009). Conceptual Modeling for Simulation: Steaming Frozen Food Processing in Vending Machine. Proceedings of the 2nd International Conference on Advanced Computer Theory and Engineering, pp. 415-423.

Zaletelj, V., Sluga, A., and Butala, P. (2008). A Conceptual Framework for the Collaborative Modeling of Networked Manufacturing Systems. Concurrent Engineering-Research and Applications, 16(1), pp. 103-114.

Zeigler, B.P. (1976). Theory of Modelling and Simulation. Wiley, Chichester, UK.

Zhang, C., Mao, H., Peng, G., and Zhang, H. (2013). A Novel BOM Based Multi-Resolution Model for Federated Simulation. (W. Shen, W. Li, J. P. Barthes, J. Luo, H. Zhu, J. Yong, and X. Li, Eds.), Proceedings of the 2013 IEEE 17th International Conference on Computer Supported Cooperative Work in Design, pp. 178-183.

Zhang, J., Kang, F., Wu, H., and Huang, W. (2012). BOM Ontology-Based Composite Modeling Approach for Simulation Model. In T. Y. Xiao, L. Zhang, and M. Fei (Eds.), Asiasim 2012, Pt I, pp. 37-45.

Zhang, M., Sang, H., Tang, J. and Ye, L. (2008). Research on the V\&V Technology of the Conceptual Model Described by UML. 7th International Conference on System Simulation and Scientific Computing Asia Simulation Conference 2008, pp. 898-902. 
Zhou, M., Son, Y., Chen, Z., Zhang, Q., and Ma, J. H. (2007). Conceptual simulation modeling: Patterns and knowledge representation. International Journal of Industrial Engineering-Theory Applications and Practice, 14(1), pp. 73-83.

Zhu, Y., Wang, W. and Zhou, D. (2008). Conceptual Framework of Composable Simulation Using Multilevel Model Specification for Complex Systems. 7th International Conference on System Simulation and Scientific Computing Asia Simulation Conference 2008, pp. 8488 .

Zou, Y., Yao, Y., Jiang, Z., and Tang, W. (2016a). An Overview of Conceptual Model for Simulation. In L. Zhang, X. Song, and Y. Wu (Eds.), Theory, Methodology, Tools and Applications for Modeling and Simulation of Complex Systems, Pt I, pp. 96-100.

Zou, Y., Yao, Y., Tang, W., and Lin, Z. (2016b). Method for Military Conceptual Modeling Based on Template Description. In M. Xu and K. Zhang (Eds.), Proceedings of the 2nd International Conference on Advances in Mechanical Engineering and Industrial Informatics, pp. 901-907. 
Appendix A: Work on the Problem/Modelling Objectives Domain

\begin{tabular}{|c|c|c|c|c|c|c|}
\hline Authors & Year & $\begin{array}{l}\text { Use of 'Soft } O R \text { ' as a } \\
\text { basis for determining a } \\
\text { simulation conceptual } \\
\text { model }\end{array}$ & $\begin{array}{l}\text { How best to work with } \\
\text { subject matter experts } \\
\text { in forming a conceptual } \\
\text { model }\end{array}$ & $\begin{array}{l}\text { How to organise and } \\
\text { structure the knowledge } \\
\text { gained during } \\
\text { conceptual modelling }\end{array}$ & $\begin{array}{l}\text { Alternative sources of } \\
\text { contextual } \\
\text { data/information for } \\
\text { conceptual modelling, } \\
\text { including paper, } \\
\text { interview and electronic } \\
\text { sources }\end{array}$ & $\begin{array}{l}\text { Developing curricula to } \\
\text { include conceptual } \\
\text { modelling in university } \\
\text { and industry courses on } \\
\text { simulation }\end{array}$ \\
\hline Ryan and Heavey * & 2007 & & & $\mathrm{X}$ & & \\
\hline Kotiadis $*$ & 2007 & $X$ & & & & \\
\hline Dickman et al & 2007 & & $X$ & $X$ & & \\
\hline Johansson et al & 2007 & & & $X$ & & \\
\hline Neumann & 2007 & & & $\mathrm{X}$ & & \\
\hline Pels and Goossenaerts & 2007 & & & & & $\mathrm{X}$ \\
\hline Zhou et al & 2007 & & & $X$ & & \\
\hline Kotiadis and Robinson & 2008 & $\mathrm{X}$ & & & & \\
\hline Turnitsa and Tolk & 2008 & & & $X$ & & \\
\hline Silver at el & 2009 & & & $X$ & & \\
\hline Tako and Kotiadis & 2010 & $X$ & & & & \\
\hline van der Zee et al & 2010 & & & & & $X$ \\
\hline Pidd ** & 2011 & $X$ & & & & \\
\hline Kotiadis $* *$ & 2011 & $\mathrm{X}$ & & & & \\
\hline Onggo and Hoare & 2011 & & $\mathrm{X}$ & & & \\
\hline $\begin{array}{l}\text { Montevechi and } \\
\text { Friend }\end{array}$ & 2012 & $\mathrm{X}$ & & & & \\
\hline Loper et al & 2012 & & & & & $\mathrm{X}$ \\
\hline Sung and Kim & 2012 & & $\mathrm{X}$ & & & \\
\hline Tako and Kotiadis & 2012 & $\mathrm{X}$ & & & & \\
\hline Ayadi et al & 2013 & & & $\mathrm{X}$ & & \\
\hline Ahmed et al & 2014 & & & $\mathrm{X}$ & & \\
\hline Figueras i Jove et al & 2014 & & & & & $\mathrm{X}$ \\
\hline Kotiadis et al & 2014 & $\mathrm{X}$ & $\mathrm{X}$ & & & \\
\hline
\end{tabular}




\begin{tabular}{|l|l|l|l|l|l|}
\hline Powell and Mustafee & 2014 & X & & & \\
\hline Ekelhart et al & 2015 & & & X & X \\
\hline Liu and Iijima & 2015 & & & & \\
\hline Pereira et al & 2015 & X & & & \\
\hline Tako and Kotiadis & 2015 & X & & & \\
\hline Sarli et al & 2016 & & & $\mathbf{4}$ & \\
\hline Total & & $\mathbf{1 1}$ & & $\mathbf{0}$ & \\
\hline
\end{tabular}

* Paper from the 2007 Journal of Simulation special issue on Conceptual Modelling (Robinson, 2007)

** Chapter in the 2011 edited book on Conceptual Modelling (Robinson et al, 2011) 


\section{Appendix B: Work on the Model Domain}

Part I: Themes 1 -6

\begin{tabular}{|c|c|c|c|c|c|c|c|}
\hline Authors & Year & $\begin{array}{l}\text { Identifying } \\
\text { dimensions for } \\
\text { determining the } \\
\text { performance of a } \\
\text { conceptual model }\end{array}$ & $\begin{array}{l}\text { Comparing } \\
\text { different models } \\
\text { in the same } \\
\text { problem domain }\end{array}$ & $\begin{array}{l}\text { Studying expert } \\
\text { modellers to } \\
\text { understand how } \\
\text { they form } \\
\text { conceptual models }\end{array}$ & $\begin{array}{l}\text { How software } \\
\text { engineering } \\
\text { techniques might } \\
\text { aid simulation } \\
\text { conceptual } \\
\text { modelling } \\
\end{array}$ & $\begin{array}{l}\text { Adopting/developi } \\
\text { ng appropriate } \\
\text { model } \\
\text { representation } \\
\text { methods }\end{array}$ & $\begin{array}{l}\text { Exploring } \\
\text { methods of model } \\
\text { simplification }\end{array}$ \\
\hline Wang and Brooks (a)* & 2007 & & & $\mathrm{X}$ & & & \\
\hline Arthur and Nance * & 2007 & & & & $\mathrm{X}$ & & \\
\hline van der Zee $*$ & 2007 & & & & & $\mathrm{X}$ & \\
\hline Pels and Goossenaerts & 2007 & & & & & $\mathrm{X}$ & \\
\hline Wang and Brooks (b) & 2007 & & & $\mathrm{X}$ & & & \\
\hline Montevechi et al & 2008 & & & & & $\mathrm{X}$ & \\
\hline Hou et al & 2008 & & & & & $\mathrm{X}$ & \\
\hline Moris et al & 2008 & & & & & & $\mathrm{X}$ \\
\hline Robinson (a) & 2008 & $\mathrm{X}$ & & & & & \\
\hline Robinson (b) & 2008 & $\mathrm{X}$ & & & & $\mathrm{X}$ & \\
\hline Tolk et al (b) & 2008 & & & & & $X$ & \\
\hline Onggo & 2009 & & & & & $\mathrm{X}$ & \\
\hline Montevechi et al & 2010 & & & & & $\mathrm{X}$ & \\
\hline Guizzardi and Wagner & 2010 & & & & $\mathrm{X}$ & & \\
\hline Wang and Brooks $* *$ & 2011 & & & $\mathrm{X}$ & & & \\
\hline Liston et al $* *$ & 2011 & & & & & $X$ & \\
\hline Ryan and Heavey ** & 2011 & & & & & $X$ & \\
\hline Onggo $* *$ & 2011 & & & & & $\mathrm{X}$ & \\
\hline Tanriover and Bilgen $* *$ & 2011 & & & & & $\mathrm{X}$ & \\
\hline Ceylan and Gunal & 2011 & & & & & $\mathrm{X}$ & \\
\hline de Assis Rangel and Nunes & 2011 & & & & $\mathrm{X}$ & $\mathrm{X}$ & \\
\hline McGinnis et al & 2011 & & & & $\mathrm{X}$ & & \\
\hline Robinson (c) & 2011 & $X$ & & & & $X$ & \\
\hline
\end{tabular}




\begin{tabular}{|c|c|c|c|c|c|c|c|}
\hline van der Zee & 2011 & & & & & $\mathrm{X}$ & \\
\hline Guizzardi and Wagner & 2012 & & & & $\mathrm{X}$ & $X$ & \\
\hline Koch et al & 2012 & & & & & $\mathrm{X}$ & \\
\hline Robinson & 2012 & $\mathrm{X}$ & & & & $\mathrm{X}$ & \\
\hline Yavari and Roeder & 2012 & $X$ & & & & & \\
\hline Batarseh et al & 2013 & & & & & $X$ & \\
\hline Greenwood et al & 2013 & & & & & $\mathrm{X}$ & \\
\hline Guizzardi and Wagner & 2013 & & & & $\mathrm{X}$ & $\mathrm{X}$ & \\
\hline Koch and Tolujew & 2013 & & & & & & $\mathrm{X}$ \\
\hline Ozhan and Oguztuzun & 2013 & & & & $\mathrm{X}$ & & \\
\hline Robinson & 2013 & $\mathrm{X}$ & & & & $\mathrm{X}$ & \\
\hline Sun et al & 2013 & & & & & $X$ & \\
\hline Ahmed et al & 2014 & & & & $\mathrm{X}$ & & \\
\hline Montevechi et al & 2014 & & & & & $\mathrm{X}$ & \\
\hline Wagner & 2014 & & & & $\mathrm{X}$ & & \\
\hline Brooks and Wang & 2015 & & & $\mathrm{X}$ & & & \\
\hline Guizzardi et al & 2015 & & & & $\mathrm{X}$ & & \\
\hline Hollmann et al & 2015 & & & & & $\mathrm{X}$ & \\
\hline Robinson & 2015 & $X$ & & & & $\mathrm{X}$ & \\
\hline Al-Fedaghi & 2016 & & & & & $\mathrm{X}$ & \\
\hline Zou et al (b) & 2016 & & & & & $\mathrm{X}$ & \\
\hline Total & & 7 & $\mathbf{0}$ & 4 & 10 & 29 & 2 \\
\hline
\end{tabular}

* Paper from the 2007 Journal of Simulation special issue on Conceptual Modelling (Robinson, 2007)

** Chapter in the 2011 edited book on Conceptual Modelling (Robinson et al, 2011) 


\section{Appendix B: Work on the Model Domain}

Part II: Themes 7 -12

\begin{tabular}{|c|c|c|c|c|c|c|c|}
\hline Authors & Year & $\begin{array}{l}\text { Identifying, } \\
\text { adapting and } \\
\text { developing } \\
\text { conceptual } \\
\text { modelling } \\
\text { frameworks }\end{array}$ & $\begin{array}{l}\text { Refining models } \\
\text { through } \\
\text { agreement } \\
\text { between the } \\
\text { modeller and } \\
\text { stakeholders - } \\
\text { 'convergent } \\
\text { design' }\end{array}$ & $\begin{array}{l}\text { Exploring the } \\
\text { creative aspects of } \\
\text { modelling }\end{array}$ & $\begin{array}{l}\text { Understanding the } \\
\text { organisational } \\
\text { diffusion and } \\
\text { acceptance of } \\
\text { models }\end{array}$ & $\begin{array}{l}\text { Investigating the } \\
\text { impact of other } \\
\text { modelling tasks on } \\
\text { the conceptual } \\
\text { model (iteration in } \\
\text { the simulation life- } \\
\text { cycle) }\end{array}$ & $\begin{array}{l}\text { Understanding the } \\
\text { effect of throw } \\
\text { away models } \\
\text { versus models } \\
\text { with longevity - } \\
\text { e.g. the time spent } \\
\text { on conceptual } \\
\text { modelling, } \\
\text { documentation } \\
\text { and organisational } \\
\text { diffusion }\end{array}$ \\
\hline Balci and Ormsby * & 2007 & $\mathrm{X}$ & & & & & \\
\hline van der Zee * & 2007 & $X$ & & & & & \\
\hline $\begin{array}{l}\text { van der Zee and van der } \\
\text { Vorst }\end{array}$ & 2007 & $X$ & & & & & \\
\hline Moris et al & 2008 & $\mathrm{X}$ & & & & & \\
\hline Robinson (a) & 2008 & $\mathrm{X}$ & & & & & \\
\hline Robinson (b) & 2008 & $\mathrm{X}$ & & & & & \\
\hline Cetinkaya et al & 2010 & $\mathrm{X}$ & & & & & \\
\hline van der Zee and Holkenborg & 2010 & $\mathrm{X}$ & & & & & \\
\hline Robinson (b) ** & 2011 & $\mathrm{X}$ & & & & & \\
\hline van der Zee ** & 2011 & $\mathrm{X}$ & & & & & \\
\hline Arbez and Birta $* *$ & 2011 & $\mathrm{X}$ & & & & & \\
\hline Karagoz and Demirors ** & 2011 & $\mathrm{X}$ & & & & & \\
\hline Haydon ** & 2011 & $\mathrm{X}$ & & & & & \\
\hline Robinson (c) & 2011 & $\mathrm{X}$ & & & & & \\
\hline Robinson & 2012 & $\mathrm{X}$ & & & & & \\
\hline Tolk and Turnitsa & 2012 & $\mathrm{X}$ & & & & & \\
\hline van der Zee & 2012 & $\mathrm{X}$ & & & & & \\
\hline van der Zee et al & 2012 & $\mathrm{X}$ & & & & & \\
\hline
\end{tabular}




\begin{tabular}{|c|c|c|c|c|c|c|c|}
\hline Adegoke et al & 2013 & $\mathrm{X}$ & & & & & \\
\hline Chwif et al & 2013 & $\mathrm{X}$ & & & & & \\
\hline Robinson & 2013 & $\mathrm{X}$ & & & & & \\
\hline Sun et al & 2013 & $\mathrm{X}$ & & & & & \\
\hline Ahmed et al & 2014 & $\mathrm{X}$ & & & & & \\
\hline Gore et al & 2014 & $\mathrm{X}$ & & & & & \\
\hline Furian et al & 2015 & $\mathrm{X}$ & & & & & \\
\hline Haveman and Bonnema & 2015 & $\mathrm{X}$ & & & & & \\
\hline Liu and Iijima & 2015 & $\mathrm{X}$ & & & & & \\
\hline Robinson & 2015 & $\mathrm{X}$ & & & & & \\
\hline van der Zee et al & 2015 & $\mathrm{X}$ & & & & & \\
\hline Arbez et al & 2016 & $\mathrm{X}$ & & & & & \\
\hline Coatanea et al & 2016 & $\mathrm{X}$ & & & & & \\
\hline Liu et al & 2016 & $\mathrm{X}$ & & & & & \\
\hline Total & & 32 & $\mathbf{0}$ & $\mathbf{0}$ & $\mathbf{0}$ & $\mathbf{0}$ & 0 \\
\hline
\end{tabular}

* Paper from the 2007 Journal of Simulation special issue on Conceptual Modelling (Robinson, 2007)

** Chapter in the 2011 edited book on Conceptual Modelling (Robinson et al, 2011) 


\section{Appendix C: New Themes}

\begin{tabular}{|c|c|c|c|c|c|c|c|}
\hline Authors & Year & $\begin{array}{l}\text { Conceptual } \\
\text { modelling and } \\
\text { model validation }\end{array}$ & $\begin{array}{l}\text { Automated code } \\
\text { generation }\end{array}$ & $\begin{array}{l}\text { Conceptual } \\
\text { modelling case } \\
\text { studies }\end{array}$ & $\begin{array}{l}\text { Domain specific } \\
\text { conceptual } \\
\text { modelling }\end{array}$ & $\begin{array}{l}\text { Concepts of } \\
\text { Conceptual } \\
\text { Modelling }\end{array}$ & $\begin{array}{l}\text { Conceptual } \\
\text { modelling and } \\
\text { model reuse, } \\
\text { interoperability } \\
\text { and composability }\end{array}$ \\
\hline Tolk and Turnitsa & 2007 & & & & & & $\mathrm{X}$ \\
\hline Yilmaz & 2007 & & & & & & $\mathrm{X}$ \\
\hline Balci et al & 2008 & & & & & & $\mathrm{X}$ \\
\hline Kilic et al & 2008 & $\mathrm{X}$ & & & & & \\
\hline Robinson (a) & 2008 & & & & & $\mathrm{X}$ & \\
\hline Robinson (b) & 2008 & & & & & $\mathrm{X}$ & \\
\hline Setavoraphan and Grant & 2008 & & & & $\mathrm{X}$ & & \\
\hline Tolk et al (a) & 2008 & & & & & & $\mathrm{X}$ \\
\hline Zaletelj et al & 2008 & & & & $\mathrm{X}$ & & \\
\hline Zhang et al & 2008 & $\mathrm{X}$ & & & & & \\
\hline Zhu et al & 2008 & & & & & & $\mathrm{X}$ \\
\hline Correia and Viegas & 2009 & & & $\mathrm{X}$ & & & \\
\hline Silver at el & 2009 & & $\mathrm{X}$ & & & & \\
\hline Wang et al & 2009 & $X$ & & & & & \\
\hline Zainuddin et al & 2009 & & & $X$ & & & \\
\hline James and Bhasi & 2010 & & & & $\mathrm{X}$ & & \\
\hline Turnitsa et al & 2010 & & & & & $X$ & \\
\hline Robinson (a) ** & 2011 & & & & & $X$ & \\
\hline Brooks ** & 2011 & & & & & $\mathrm{X}$ & \\
\hline Tolk et al ** & 2011 & & & & & & $\mathrm{X}$ \\
\hline Tanriover and Bilgen $* *$ & 2011 & $\mathrm{X}$ & & & & & \\
\hline Pace ** & 2011 & & & & $\mathrm{X}$ & & \\
\hline Sprenger and Rose $* *$ & 2011 & & & & $\mathrm{X}$ & & \\
\hline van der Zee et al $* *$ & 2011 & & & & & $\mathrm{X}$ & \\
\hline Balci et al & 2011 & & & & & & $\mathrm{X}$ \\
\hline Cetinkaya et al & 2011 & & $\mathrm{X}$ & & & & \\
\hline
\end{tabular}




\begin{tabular}{|c|c|c|c|c|c|c|c|}
\hline Ceylan and Gunal & 2011 & & $\mathrm{X}$ & & & & \\
\hline Durak et al & 2011 & & & & & & $\mathrm{X}$ \\
\hline McGinnis et al & 2011 & & $\mathrm{X}$ & & & & \\
\hline Robinson (c) & 2011 & & & & & $\mathrm{X}$ & \\
\hline Gianni et al & 2012 & & & & & & $\mathrm{X}$ \\
\hline James and Bhasi & 2012 & & & & $\mathrm{X}$ & & \\
\hline Robinson & 2012 & & & & & $\mathrm{X}$ & \\
\hline Zhang et al & 2012 & & & & & & $\mathrm{X}$ \\
\hline Bair and Tolk & 2013 & $\mathrm{X}$ & & & & & \\
\hline Gu et al & 2013 & $\mathrm{X}$ & & & & & \\
\hline Ozhan and Oguztuzun & 2013 & & $\mathrm{X}$ & & & & \\
\hline Robinson & 2013 & & & & & $\mathrm{X}$ & \\
\hline Yaroker et al & 2013 & $\mathrm{X}$ & & & & & \\
\hline Zhang et al & 2013 & & & & & & $\mathrm{X}$ \\
\hline Gore et al & 2014 & $\mathrm{X}$ & & & & & \\
\hline Grakova et al & 2014 & & & & $\mathrm{X}$ & & \\
\hline Cetinkaya et al & 2015 & & $\mathrm{X}$ & & & & \\
\hline Hollmann et al & 2015 & & $\mathrm{X}$ & & & & \\
\hline Luetjen and Rippel & 2015 & & $\mathrm{X}$ & & & & \\
\hline Robinson & 2015 & & & & & $\mathrm{X}$ & \\
\hline Robinson et al & 2015 & & & & & $\mathrm{X}$ & \\
\hline Roca et al & 2015 & & & & & $\mathrm{X}$ & \\
\hline Sales and Guizzardi & 2015 & $\mathrm{X}$ & & & & & \\
\hline Tolk & 2015 & & & & & & $\mathrm{X}$ \\
\hline Turner and Mavris & 2015 & $\mathrm{X}$ & & & & & \\
\hline van der Zee et al & 2015 & & & & $\mathrm{X}$ & & \\
\hline Liu et al & 2016 & & & & & & $\mathrm{X}$ \\
\hline Zou et al (a) & 2016 & & & & & $\mathrm{X}$ & \\
\hline Mensah et al & 2017 & & & $X$ & & & \\
\hline Total & & 10 & 8 & 3 & 8 & 13 & 13 \\
\hline
\end{tabular}

* Paper from the 2007 Journal of Simulation special issue on Conceptual Modelling (Robinson, 2007)

** Chapter in the 2011 edited book on Conceptual Modelling (Robinson et al, 2011) 